\title{
Reinterpreting a Proterozoic enigma: Conophyton-Jacutophyton stromatolites of the Mesoproterozoic Atar Group, Mauritania
}

\author{
LINDA C. KAH ${ }^{*}$, JULIE K. BARTLEY ${ }^{\dagger}$ and ALICE F. STAGNER ${ }^{\ddagger}$ \\ *Department of Earth \& Planetary Sciences, University of Tennessee, Knoxville, TN 37996, USA \\ (E-mail:1ckah@utk.edu) \\ ${ }^{\dagger}$ Department of Geosciences, University of West Georgia, Carrollton, GA 30118, USA \\ ${ }^{\ddagger}$ School of Geology and Geophysics, University of Oklahoma, Norman, OK 73019, USA
}

\begin{abstract}
The Mesoproterozoic Atar Group, Taoudeni Basin, Mauritania, preserves a spectacular diversity of stromatolite morphologies, including stromatolitic biostromes comprised of the conical form Conophyton, the enigmatic branching conical form Jacutophyton, and a variety of irregularly branching forms, including Tilemsina and Baicalia. Until now, the peculiar juxtaposition of high- and low-relief stromatolite morphologies has posed a conundrum for environmental interpretation of stromatolite forms, and has led to interpretations of strict biological control over stromatolite morphology. Careful assessment of superpositional relationships among stromatolite elements, however, suggests that the diversity of stromatolite morphologies in the Atar Group can be readily explained via parasequence-scale sea-level changes and the incomplete and laterally discontinuous filling of accommodation space. In the Atar Group, biostrome growth initiates during relative rises in sea level with the widespread, subtidal nucleation of Conophyton. Exposure of Conophyton to wave energy during falls in relative sea level result in disruption of stromatolitic laminae, generation of interstromatolitic debris, and development of both superimposed and laterally adjacent branching stromatolite forms. In this scenario, the enigmatic stromatolite form Jacutophyton represents stromatolite growth through a complete depositional parasequence, and the unusual juxtaposition of stromatolite forms reflects growth of different forms that is separated by time and depositional environment. With subsequent rises in sea level, nucleation of new Conophyton in subtidal regions, and continued growth of branching forms and aggradation of the depositional substrate in intertidal regions, results in continued modification of sea-floor topography. In the model presented here, stratigraphic time is partitioned both vertically and laterally during biostrome growth, resulting in a complex internal architecture that is not readily discerned in outcrop. In connecting hydrodynamic variables to stromatolite morphology, this model provides a more comprehensive understanding of Atar Group stromatolites in terms of basin geometry, relative sea level and carbonate production.
\end{abstract}

Keywords Proterozoic, stromatolites, Jacutophyton, Conophyton, Mauritania, Atar Group, biostrome architecture, parasequence development.

\section{INTRODUCTION}

Whereas stromatolite microfabrics are generally believed to reflect a combination of microbial community growth, decomposition and lithification (Golubic, 1976; Bertrand-Sarfati, 1983; Turner et al., 1993; Knoll \& Sergeev, 1995; Kah \& Knoll, 1996; Knoll \& Semikhatov, 1998; Grotzinger \& Knoll, 1999; Lee \& Golubic, 2000; Reid et al., 2000), stromatolite morphology appears to be affected more strongly by physical depositional factors, particularly water depth, wave energy and sediment influx (Cloud \& Semikhatov, 1969; Semikhatov et al., 1979; Semikhatov \& Raaben, 1994, 1996; Andres \& Reid, 2006). As a result, stromatolitic laminae, which record both microscale and macroscale growth processes, are arguably the most fundamental aspect of stromatolite morphology (Walter, 1992). Each lamina represents the active growth surface of the mat at the time of deposition and therefore records the topography of the depositional surface (i.e. synoptic relief, Hofmann, 1969; Donaldson, 1976), the relative rates of stromatolite growth and 
sediment infilling (i.e. wall structure, Hofmann, 1969; Semikhatov et al., 1979) and the influence of wave and/or current action on mat growth (i.e. stromatolite elongation, Hoffman, 1967; Logan et al., 1974). Not only do laminae closely record the morphology of a microbial mat on the seafloor, but the geometry of successive laminae also produces a record of microbial mat growth over time that is reflected in stromatolite morphology. More recently, process-oriented models (Grotzinger \& Rothman, 1996; Grotzinger \& Knoll, 1999; Dupraz et al., 2006) have emphasized the importance of laminae geometry by using variable interface parameters including surface roughness (mat growth and degradation), upward growth (mineral precipitation) and surface dampening (draping sedimentation) to simulate lamina accretion and stromatolite morphogenesis.

The relationship between stromatolite morphology and depositional setting has been examined in a number of key studies (Hoffman, 1974; Donaldson, 1976; Grey \& Thorne, 1985; Bertrand-Sarfati \& Moussine-Pouchkine, 1985). These studies, summarized by Hoffman (1976) and Grotzinger (1989), indicate that specific stromatolite morphologies represent distinct depositional settings and are well correlated with inferred palaeowater depth, water energy and sediment supply. Upper intertidal to supratidal environments are characterized by stromatolites with low synoptic relief, frequently associated with intraclastic debris. Intertidal to shallow subtidal (above fair weather wave-base) environments are characterized by relatively low-relief domal and irregular columnar stromatolites associated with intraclastic and/or fine-grained detrital material. Deeper subtidal (below fair weather wavebase) environments are characterized by high-relief columnar to conical stromatolite forms that lack evidence of interstromatolitic sediment deposition. Empirically, relationships between stromatolite morphology and inferred depositional parameters appear relatively robust, yet similar relationships observed in modern environments highlight potential variability resulting from local and regional variation in accommodation space, hydrodynamic regime and patterns of sediment deposition (Andres \& Reid, 2006).

The Proterozoic Atar Group, exposed along the northern edge of the Taoudeni Basin in Mauritania, Mali and Algeria, preserves a spectacular diversity of stromatolite morphologies, including three distinct biostromes composed of the conical stromatolite form Conophyton, the enigmatic branching conical stromatolite Jacutophyton and a variety of irregularly branching forms, including Tilemsina and Baicalia (Bertrand-Sarfati, 1972; BertrandSarfati \& Moussine-Pouchkine, 1999). These bioherms, herein referred to as Atar Formation biostromal units R1-R3, show striking stratigraphic similarity in both western (Mauritania) and eastern (Mali-Algeria) sections of the Taoudeni Basin, and have been interpreted as regional reef tracts that played a critical role in basin development (Bertrand-Sarfati \& Moussine-Pouchkine, 1992, 1999; Moussine-Pouchkine \& BertrandSarfati, 1997).

Two aspects of the Atar Formation biostromes, however, pose a conundrum for an environmental interpretation of stromatolite morphology. First, biostromal intervals do not exhibit the large-scale changes in geometry that are commonly observed in stromatolite reefs and interpreted as resulting from changes in sea level or accommodation space (Grotzinger, 1989; Narbonne \& James, 1996; Turner et al., 1997; Lemon, 2000). Second, peculiar juxtaposition of conical and branching stromatolite forms (Fig. 1), such as laterally adjacent Conophyton and Jacutophyton or Conophyton and Tilemsina, which typically occur in distinct depositional environments, has been used to conclude that microbial community structure, rather than depositional environment, may exert the primary control over stromatolite morphology (Bertrand-Sarfati \& Moussine-Pouchkine, 1985).

Recent work in the Mesoproterozoic Dismal Lakes Group provides a framework for interpreting the enigmatic relationships observed in the Atar Group biostromes (Kah et al., 2006). The Dismal Lakes reef consists of a thin $(<40 \mathrm{~m})$, laterally extensive $\left(>2400 \mathrm{~km}^{2}\right)$ biostromal complex that contains both exceptionally high-relief (up to $15 \mathrm{~m}$ ) conical stromatolites and lower relief domal and columnar forms. In the Dismal Lakes Group, relationships among stromatolites are best explained in terms of the sea-level history of the platform, wherein high-frequency (i.e. parasequence-scale) sea-level changes produce a complex internal reef architecture, which results from lateral juxtaposition of facies across non-horizontal timelines (Kah et al., 2006). High-relief conical stromatolites initiated during major transgression and reflect transgressive and highstand stromatolite growth. Subsequent sea-level fall exposed the tops of these conical stromatolites, creating a sequence boundary that traced the rugged seafloor topography delineated by the decametre-scale synoptic relief of the stromatolites. During the sea-level cycles that followed, lower-relief domal and columnar stromatolites 

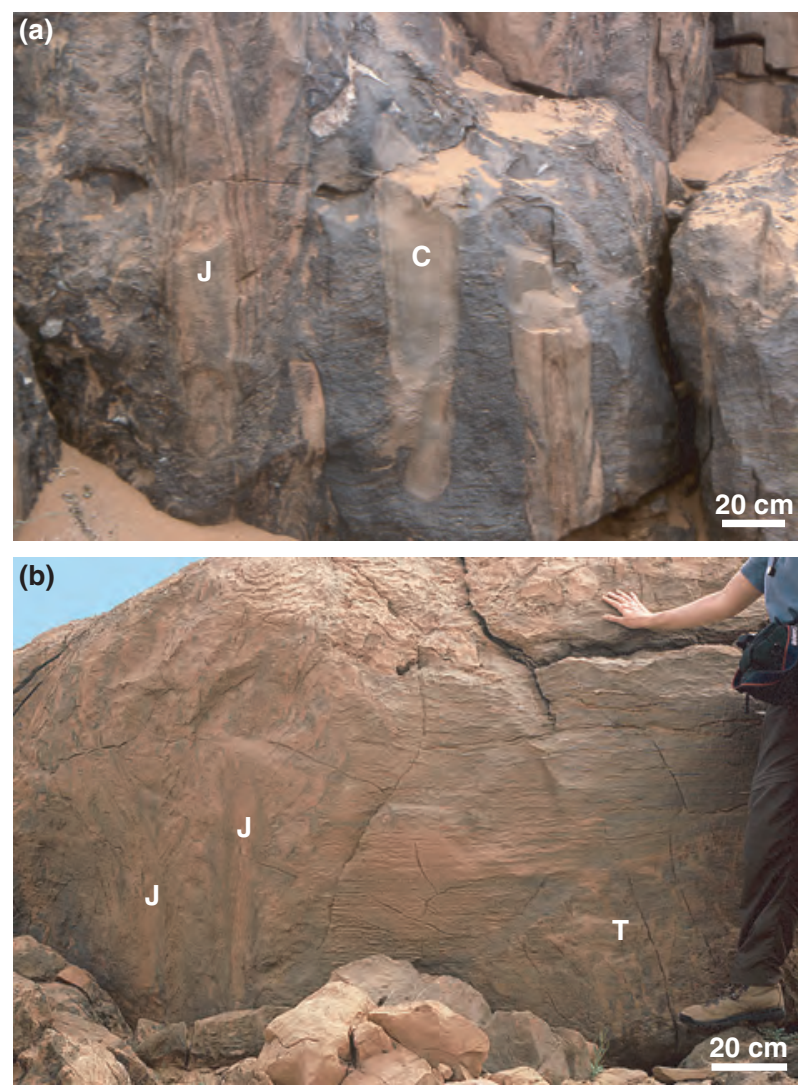

Fig. 1. Enigmatic juxtaposition of stromatolite forms in the Atar Formation. (a) Conophyton-Jacutophyton in the R1 reef interval. (b) Jacutophyton-Tilemsina in the R2 reef interval.

grew on this rugged surface, filling space between the high-relief cones. The resultant stromatolite biostrome exhibits lateral partitioning of time, with conical stromatolite growth dominating during relative sea-level rise and domal to columnar stromatolite growth occurring during times of lower accommodation space (Kah et al., 2006).

In this paper, we provide a stratigraphic interpretation of the enigmatic Atar Formation Conophyton-Jacutophyton biostromes. Here, we (1) document superpositional relationships among stromatolitic elements in the Atar Formation biostromes; (2) interpret stromatolite growth in terms of relative sea-level change; and (3) explore stromatolite and sea-level relationships in terms of basin geometry and Proterozoic carbonate dynamics.

\section{GEOLOGICAL SETTING AND AGE}

The Taoudeni Basin, West Africa, preserves up to $1300 \mathrm{~m}$ of gently dipping $\left(<1^{\circ}\right)$, unmetamorphosed,

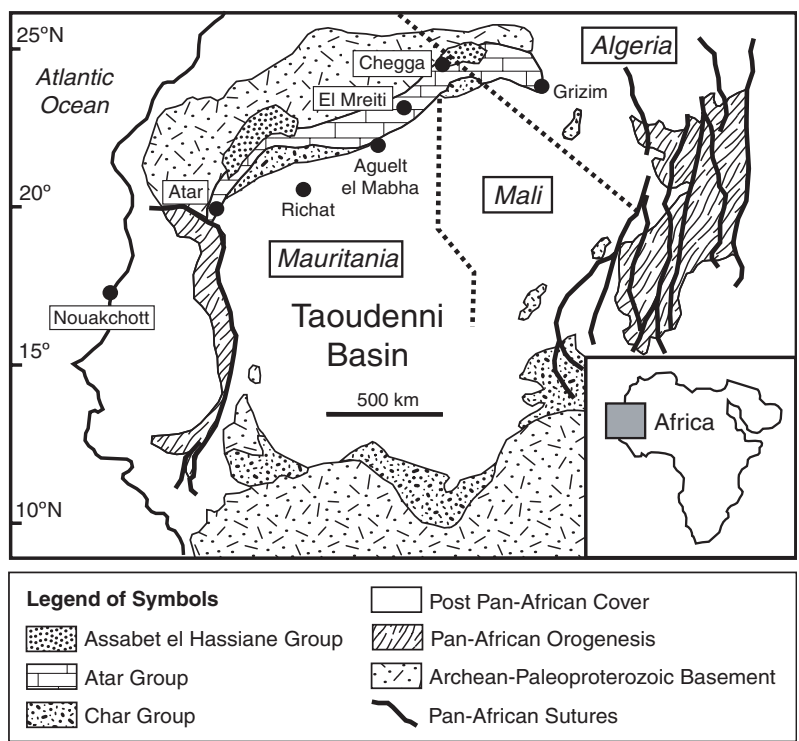

Fig. 2. Regional extent of the Atar Group. Atar Group strata are exposed in a continuous belt across the West African craton from Mauritania to western Algeria. Atar Group strata unconformably overlie predominantly siliciclastic strata of the Char Group, onlap Archaean-Palaeoproterozoic rocks of the Regubiat Shield and are overlain by siliciclastic strata of the Assabet el Hassiane Group. Variously deformed, stromatolitic strata in the Hoggar Uplift, Mali and Algeria, may represent depositional equivalents to the Atar Group (Bertrand-Sarfati \& Trompette 1976; BertrandSarfati et al., 1987).

and virtually undeformed Proterozoic strata that crop out in a sinuous belt spanning $>1500 \mathrm{~km}$ from Mauritania to northern Mali and Western Algeria (Fig. 2). Strata unconformably overlie Archaean amphibolite and quartzo-feldspathic schists and Palaeoproterozoic granitic intrusions of the Reguibat Shield (Black \& Fabre, 1983; Trompette \& Carozzi, 1994) and are in turn unconformably overlain by Vendian (or Cambrian) and younger strata (Clauer \& Deynoux, 1987; BertrandSarfati et al., 1995).

Proterozoic strata of the Taoudeni Basin are typified by well-exposed sections in the Adrar Mountains of Mauritania, where the succession is subdivided into three unconformity-bounded groups (Figs 2 and 3). Potentially correlative and similarly subdivided strata are also exposed in the Hoggar uplift of Algeria (Moussine-Pouchkine et al., 1988; Bertrand-Sarfati et al., 1991, 1996; Moussine-Pouchkine \& Bertrand-Sarfati, 1997) and in several poorly studied exposures in the southern Taoudeni Basin (Bertrand-Sarfati \& Moussine-Pouchkine, 1983; Bertrand-Sarfati et al., 1987). At the base of the succession, coarse- to 


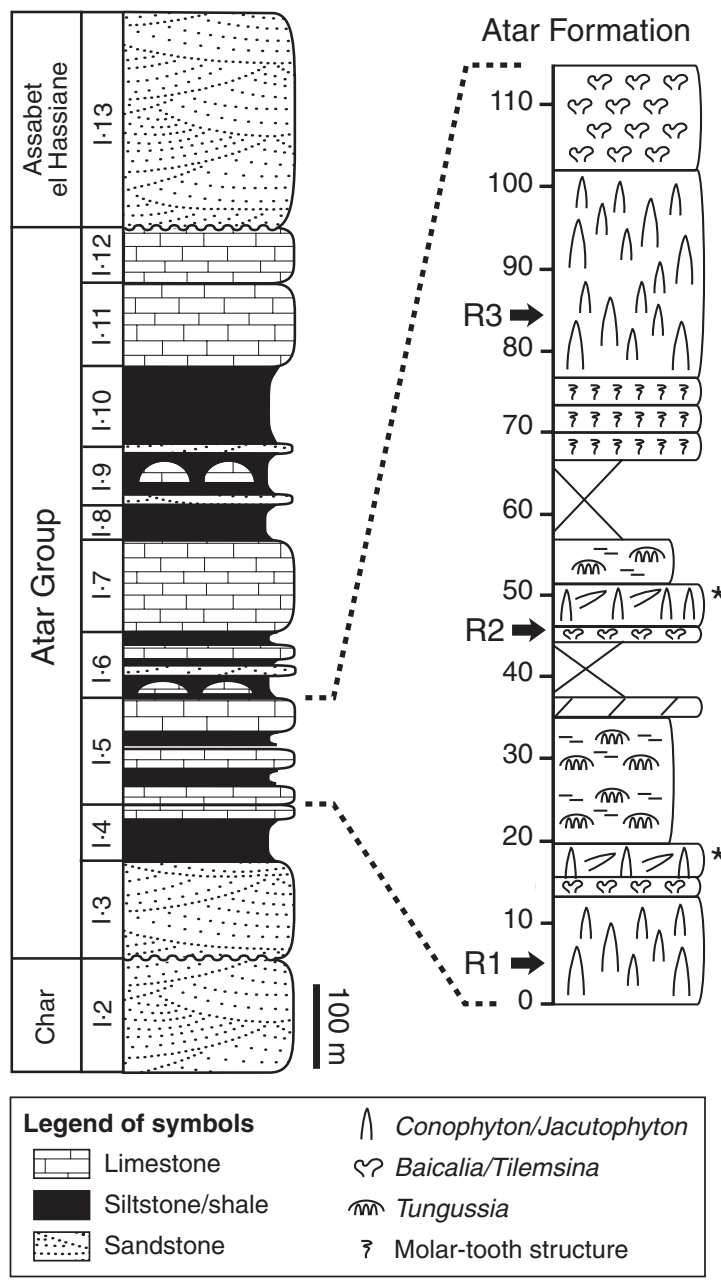

Fig. 3. Stratigraphy of the Atar Group. The $\sim 750 \mathrm{~m}$ thick Atar Goup consists of ten formations (I-3, Foum Chor; I-4, Ksar Torchane; I-5, Atar; I-6, Oued Tariofet; I-7, Tawaz; I-8, Oued Terrarit; I-9, Aouinet Ould Bou Derbala; I-10, Aouleigate; I-11, Touiderguilt; I-12, Tifounke) that record deposition of fine-grained siliciclastic and carbonate sediment. The Atar Formation (I-5) is marked by deposition of three prominent Conophyton-Jacutophyton reefs (R1-R3). Each reef interval initiates at a marine transgression and represents transgressive to highstand systems tract deposition. Deposition of the lower two reef intervals terminates at an abrupt fall in relative sea level (marked by asterisks) and is followed by deposition of a predominantly siliciclastic lowstand systems tract. The uppermost reef interval is marked by a gradual fall in relative sea level, and is overlain by lowstand siliciclastic, carbonate, and evaporite deposition of the Oued Tariofet Formation (I-6).

fine-grained siliciclastic strata and subordinate carbonates of the Char Group are preserved as erosional remnants in cratonal depressions and represent initial mantling of the craton by fluvial, coastal aeolian and shallow-marine deposits (Benan \& Deynoux, 1988). In contrast to the Char Group, fine-grained siliciclastic strata, stromatolite-bearing carbonate and minor evaporitic strata (Goodman \& Kah, 2004) of the Atar Group represent craton-wide flooding and deposition in predominantly shallow marine environments (Bertrand-Sarfati \& Moussine-Pouchkine, 1988). The overlying Assabet el Hassiane Group is composed of deep to shallow marine, fine-grained siliciclastic strata (Trompette \& Carozzi, 1994; Moussine-Pouchkine \& Bertrand-Sarfati, 1997).

The most lithologically variable of these successions, the $\sim 750 \mathrm{~m}$ thick Atar Group, consists of ten formations that record alternating deposition of stromatolite-bearing carbonate and siliciclastic material (Fig. 3; Bertrand-Sarfati \& MoussinePouchkine, 1988, 1999). The basal Foum Chor (unit I-3) Formation is markedly more coarsegrained than the remainder of the Atar Group, and consists primarily of fining-upward, coarseto medium-grained fluvial to fluvial-marine sandstones that onlap both the Reguibat Shield and deeply incised strata of the Char Group. Remaining formations (Ksar Torchane, unit I-4; Atar, unit I-5; Oued Tariofet, unit I-6; Tawaz, unit I-7; Oued Terrarit, unit I-8; Aouinet Ould Bou Derbala, unit I-9; Aouleigate, unit I-10; Touiderguilt, unit I-11; and Tifounke, unit I-12) preserve regionally extensive depositional packages of siltstone and shale alternating with stromatolite-bearing carbonate and subordinate evaporites. Spectacular stromatolite biostromes of the Atar Group (R1-R3 of the Atar Formation, unit I-5) are the focus of this study. The presence of hummocky crossstratification, wave and interference ripples, and lenses of flat-pebble conglomerates in siliciclastic strata suggests predominantly shallow subtidal to intertidal depositional environments. Subtidal to intertidal depositional environments are also inferred from stromatolite morphologies in the Atar Group (Bertrand-Sarfati, 1972; BertrandSarfati \& Moussine-Pouchkine, 1985), suggesting that the alternation of siliciclastic and carbonate strata may result primarily from regional climatic or tectonic activity and the episodic influx of siliciclastic material from source areas outside the Taoudeni basin (Bertrand-Sarfati \& MoussinePouchkine, 1988; Moussine-Pouchkine \& Bertrand-Sarfati, 1997).

The age of the Atar Group is poorly constrained. $\mathrm{Rb}-\mathrm{Sr}$ geochronology (Clauer, 1976, 1981; Clauer et al., 1982) performed on glauconite and illite in shaly intervals provide ages from $998 \pm 32 \mathrm{Ma}$ (Azougi Formation, unit I-2, underlying Char Group) to >694 Ma (Assabet el Hassiane Group, unit I-15), with most formations in the Atar 
Group constrained by a single age $(890 \pm 35 \mathrm{Ma}$, Atar Formation, unit I-5; $874 \pm 22 \mathrm{Ma}$, Oued Tarioufet Formation, unit I-6; $866 \pm 67 \mathrm{Ma}$, Oued Terrarit Formation, unit I-8; $775 \pm 52 \mathrm{Ma}$, Aouleigate Formation, unit I-10).

Although these $\mathrm{Rb}-\mathrm{Sr}$ ages clearly represent diagenetic mineralization, the consistent decrease in ages through the stratigraphic column has been used to argue for early diagenetic stabilization of clay minerals and Neoproterozoic depositional ages for these strata. By contrast, recent C-isotope data from the Atar Group (Fairchild et al., 1990; Teal \& Kah, 2005) reveal moderately positive $\delta^{13} \mathrm{C}$ values near $+2 \%$ with several distinct negative excursions to nearly $-2.5 \%$. The range of C-isotope values preserved in the Atar Group is inconsistent with the strongly positive values $\left(\delta^{13} \mathrm{C}>+5 \%\right.$ ) recorded in well-constrained isotopic compilations for the post-850 Ma Neoproterozoic (Kaufman \& Knoll, 1995; Halverson et al., 2005). Atar Group chemostratigraphy is also distinctly different from that of strata probably deposited in the earliest Neoproterozoic (Knoll et al., 1995; Bartley et al., 2001) and more closely reflects isotopic patterns preserved globally in mid to late Mesoproterozoic strata (Knoll et al., 1995; Kah et al., 1999a; Bartley et al., 2001, 2007; Frank et al., 2003; ), suggesting that the Atar Group may be as old as 1200 Ma.

\section{STROMATOLITE BIOSTROMES OF THE ATAR FORMATION}

\section{Lithology and sequence stratigraphic framework}

Like the rest of the Atar Group, the $\sim 125 \mathrm{~m}$ thick Atar Formation (unit I-5) consists of alternating fine-grained siliciclastic strata and stromatolitebearing carbonate (Fig. 3). Siliciclastic intervals are composed primarily of dark coloured shale containing laterally discontinuous interbeds of fine-grained sandstone and a variable carbonate component. Basal siliciclastic strata contain abundant thin ( $<1 \mathrm{~m}$ thick) interbeds of fine-grained, flat-laminated microbial carbonate and flat-clast breccia, and mark shallow-water lowstand deposition following regional flooding and deposition of shallow-marine carbonate strata of the Ksar Torchane Formation (unit I-4). Similarly, stratigraphically higher siliciclastic intervals represent lowstand deposition following craton-wide flooding and development of the Atar Formation Conophyton-Jacutophyton biostromes (Bertrand-Sarfati \& Moussine-Pouchkine,
1988). Disappearance of flat-clast breccias and flat-laminated microbial carbonate interbeds in stratigraphically higher siliciclastic intervals and their replacement by small ( $<2 \mathrm{~m}$ thick) discontinuous bioherms of irregularly branching columnar stromatolites (Tungussia confusa; BertrandSarfati \& Moussine-Pouchkine, 1999), as well as rare intervals of 'molar-tooth' carbonate (Furniss et al., 1998; James et al., 1998; Pollock et al., 2006) suggest shallow-marine deposition and overall greater accommodation space across the platform.

Carbonate-dominated intervals in the Atar Formation form three distinct stromatolite biostromes (R1-R3, 9-39m thick; Fig. 3) that are the focus of this study. Biostromal intervals typically preserve a thin ( $<1 \mathrm{~m}$ thick) and discontinuous transgressive horizon at their base, composed of flat-clast breccia and low relief, divergent branching stromatolites (Tilemsina divergens; BertrandSarfati \& Moussine-Pouchkine, 1999). The main biostromes are composed of conical to branching conical stromatolites (Conophyton ressoti, Conophyton jacqueti and Jacutophyton sahariensis; Bertrand-Sarfati \& Moussine-Pouchkine, 1999) that are interpreted to have developed as deep-water reef tracts $(80-100 \mathrm{~m}$; BertrandSarfati \& Moussine-Pouchkine, 1985) during highstand conditions. Termination of each biostrome appears to have resulted from loss of accommodation space. Termination of the R1 biostrome is marked by regional toppling of Conophyton (Fig. 4a), suggesting an abrupt decrease in accommodation space and impingement of storm wave base on the biostrome. Similarly, termination of the R2 biostrome is marked by a regional pavement of broken Conophyton and stromatolitic breccia (Fig. 4b), suggesting an abrupt decrease in accommodation space and prolonged exposure of the biostrome. By contrast, termination of the R3 biostrome is marked by a transition from dominantly conical stromatolites to a $10 \mathrm{~m}$ thick interval of irregularly branching forms (Baicalia safia and Baicalia mauritanica; Bertrand-Sarfati \& Moussine-Pouchkine, 1999) that are overlain by black shale and 'molar-tooth' carbonate of the lower Oued Tarioufet Formation (unit I-6). Gradational contacts between stromatolite morphologies in the R3 biostrome suggest a gradual decrease in accommodation space driven by aggradational growth of the biostrome complex.

Combined, lithological and stratigraphic features indicate that the Atar Formation biostrome complexes developed during a series of 

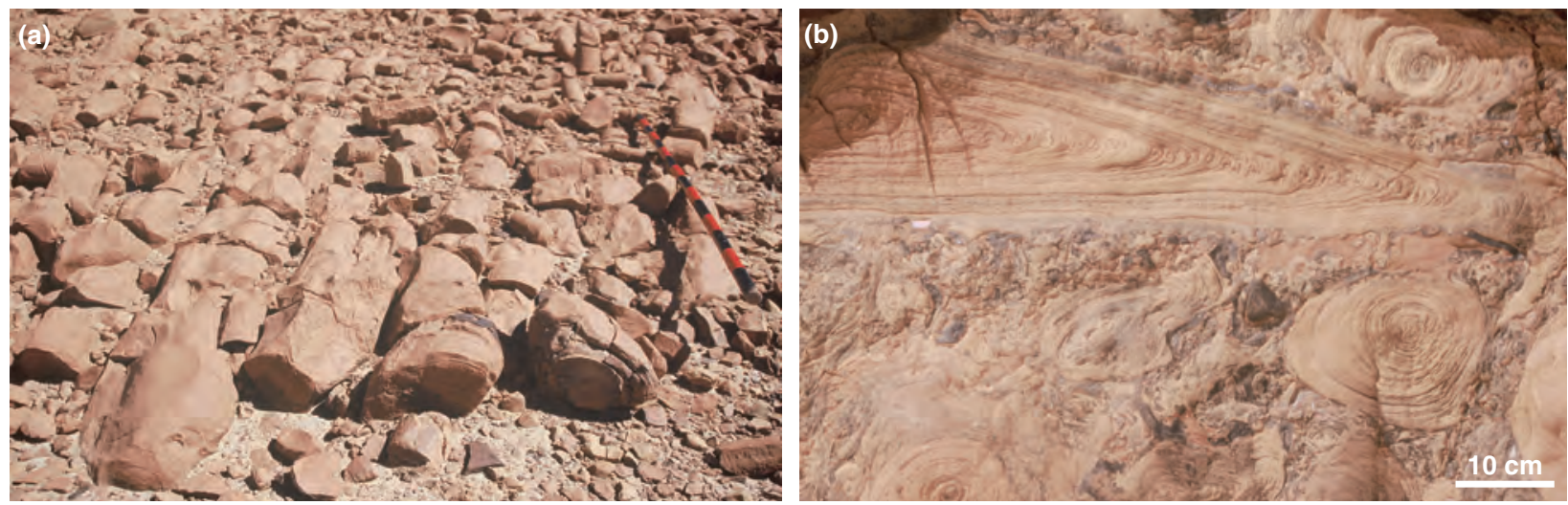

Fig. 4. Termination of stromatolite reef deposition. (a) Termination of the R1 reef interval is marked by regional toppling of Conophyton; oblique bedding plane view; Jacob staff marked in $10 \mathrm{~cm}$ intervals. (b) Termination of the R2 reef interval is marked by a regional pavement of broken Conophyton and stromatolitic breccia; bedding plane view.

thin (30-50m thick) third-order stratigraphic sequences (Emery \& Meyers, 1996; Miall, 1997). The base of each biostromal complex is marked by a transgressive surface and initiation of deep-water stromatolite growth. Stromatolite growth continued during transgressive and highstand phases and was terminated by a loss of accommodation space, either by a fall in sea level or continued aggradation of the biostrome complex. Finally, biostromes are overlain by late highstand to lowstand, shale-dominated deposits. Relatively thin sequences and abrupt transitions between siliciclastic and carbonate facies reflect a cratonal sedimentation regime (Bertrand-Sarfati \& Moussine-Pouchkine, 1988), wherein minimal subsidence and the extremely low relief of the sedimentary substrate resulted in dramatic changes in depositional environment with even small changes in accommodation space.

\section{Reef elements}

\section{Conical stromatolites}

Conical stromatolites (Conophyton spp.) are the most common element of the Atar Formation biostromes (Fig. 5a), and a number of form-taxa have been recognized, including Conophyton ressoti and Conophyton jacqueti (BertrandSarfati \& Moussine-Pouchkine, 1985, 1999). Conical stromatolites have steeply dipping $\left(75^{\circ}-90^{\circ}\right)$ wall-parallel laminae, narrow and nearly vertical axial zones and high synoptic relief. Synoptic relief of a stromatolite above the seafloor is delineated by the height of a single lamina, which represents the morphology of the seafloor at the time of lamina formation (Hofmann, 1969). Inheritance of antecedent topography in these stromatolites is high, and a single columnar structure often represents several distinct phases of stromatolite growth, with each cone growing directly atop the previous structure (Fig. 6a). Thus, a column may be up to $4 \mathrm{~m}$ tall; however, no single lamina exceeds $2 \mathrm{~m}$ in height, indicating that individual stromatolites stood no more than $2 \mathrm{~m}$ above the seafloor at any one time. Despite a generally uniform shape, differences in morphology are apparent. Cross-sectional shapes range from circular (C. ressoti) to elliptical (C. jacqueti; Fig. 6b; see discussion in BertrandSarfati \& Moussine-Pouchkine, 1999), and individual cones may display thickening of outer laminae, forming superficial protrusions along the outer surface of the cone (Fig. 6b). Cones also show variable modification after growth, including delamination (Fig. 6c) and erosional incision (Fig. 6d) of cone margins.

Individual conical stromatolites range in diameter from 10 to $50 \mathrm{~cm}$ and show interstromatolitic spacing of $5-70 \mathrm{~cm}$. Interstromatolitic regions contain both platy breccia and fine-grained detrital carbonate, as well as several generations of precipitated carbonate cement (cf. Fig. 9; see descriptions below). The high synoptic relief of stromatolitic laminae suggests that conical stromatolites formed largely below wave base, in quiet-water environments, and that lithification occurred largely through in situ carbonate precipitation (cf. Bertrand-Sarfati \& Moussine-Pouchkine, 1985; Kah et al., 2006). Although high synoptic relief may have inhibited incorporation of sediment from the water column into the Conophyton, 

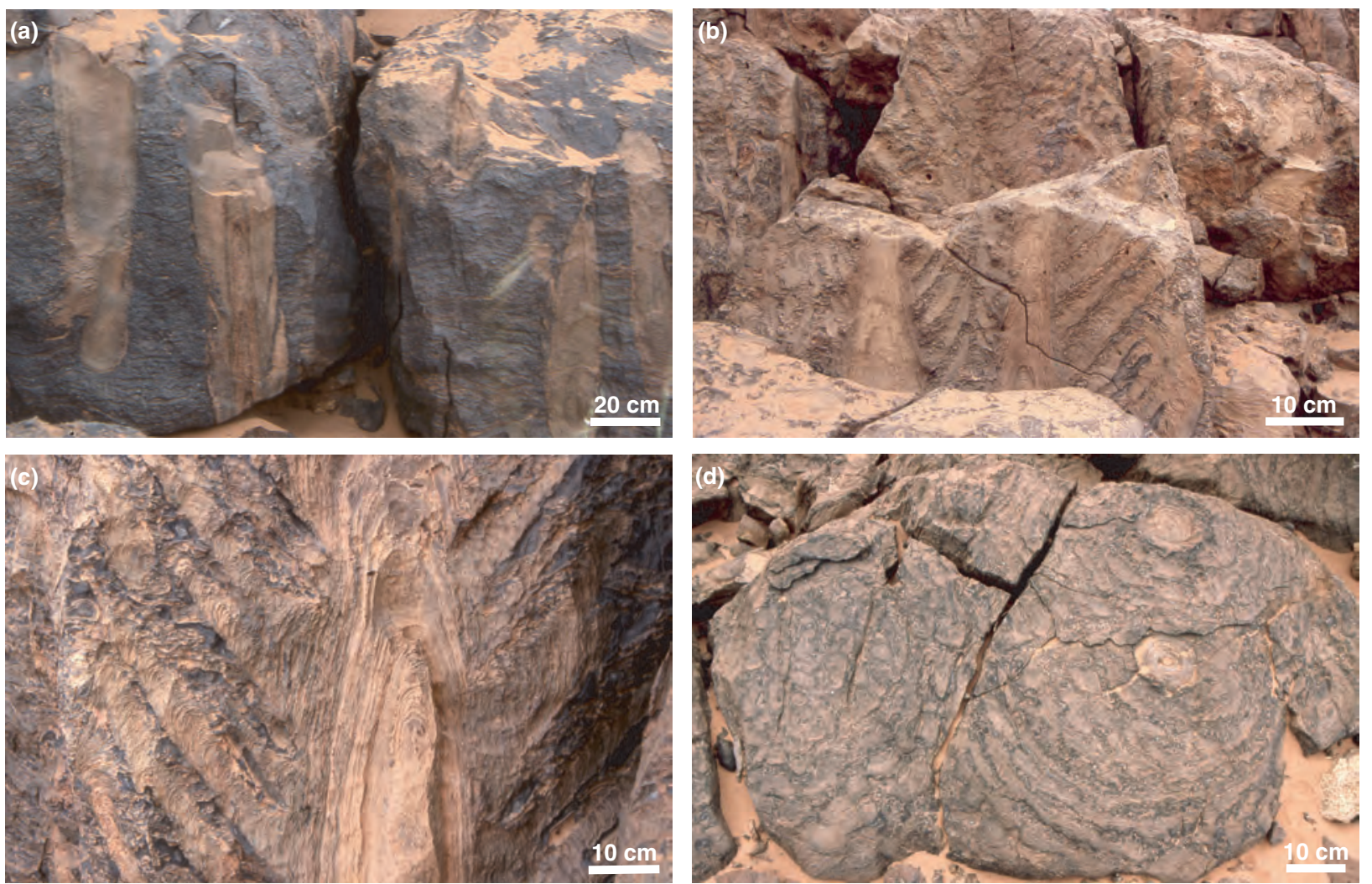

Fig. 5. Conophyton-Jacutphyton association of the Atar Formation. (a) High synoptic relief and nearly vertical, parallel laminae characterize Conophyton within the Atar Formation reefs. Conophyton ressoti (shown here) bears a single central axial zone and occurs in R1 and R2 reef intervals; Conophyton jacqueti has an expanded axial zone, an elongate cross-section and occurs primarily in the R3 reef interval. (b) The enigmatic stromatolite Jacutophyton sahariensis is characterized by low synoptic relief branches that surround a conical central core. (c) Detailed cross-sectional view of Jacutophyton showing oblique growth of branching elements. (d) Oblique bedding plane view of Jacutophyton highlighting the petaloid nature of branching elements that encompass the central cone.

the continuous walled nature of stromatolite margins and general absence of erosion resulting from sediment entrained within this water column supports the paucity of detrital sediment at the time of cone growth. Rarely, successive laminae in the basal 3-5 cm of conical stromatolites record an abrupt onlapping of fine-grained interstromatolitic sediment, suggesting that at least small amounts of detrital sediment may have been deposited during Conophyton growth. Combined, these observations suggest that interstromatolitic debris represents sediment deposition that occurred predominantly after stromatolite growth.

\section{Branching conical stromatolites}

Along with Conophyton, branching-conical stromatolites (Jacutophyton sahariensis) form conspicuous elements of the Atar Formation biostromes.
Jacutophyton consists of a central conical region, indistinguishable from Conophyton, that is surrounded by low synoptic relief, unwalled to moderately walled, columnar branches (Figs 5b, c and 7a). Branching elements are moderately to highly divergent from the central cone, extend up to $50 \mathrm{~cm}$ from the cone margin (Fig. 5b), and are subcylindrical to petaloid in form, forming elliptical to elongate cross-sections that encircle the central cone (Fig. 5d). With rare exception, branches initiate along a single laminae of the central cone (Fig. 7a). In Jacutophyton, branching occurs along the entire height of the central cone, although in the Atar Formation biostromes, branching elements variously attributable to Baicalia or Tilemsina (Fig. 7b) are occasionally concentrated in the uppermost portion of the central cone or on pavements of broken or toppled Conophyton (Fig. 7c). 

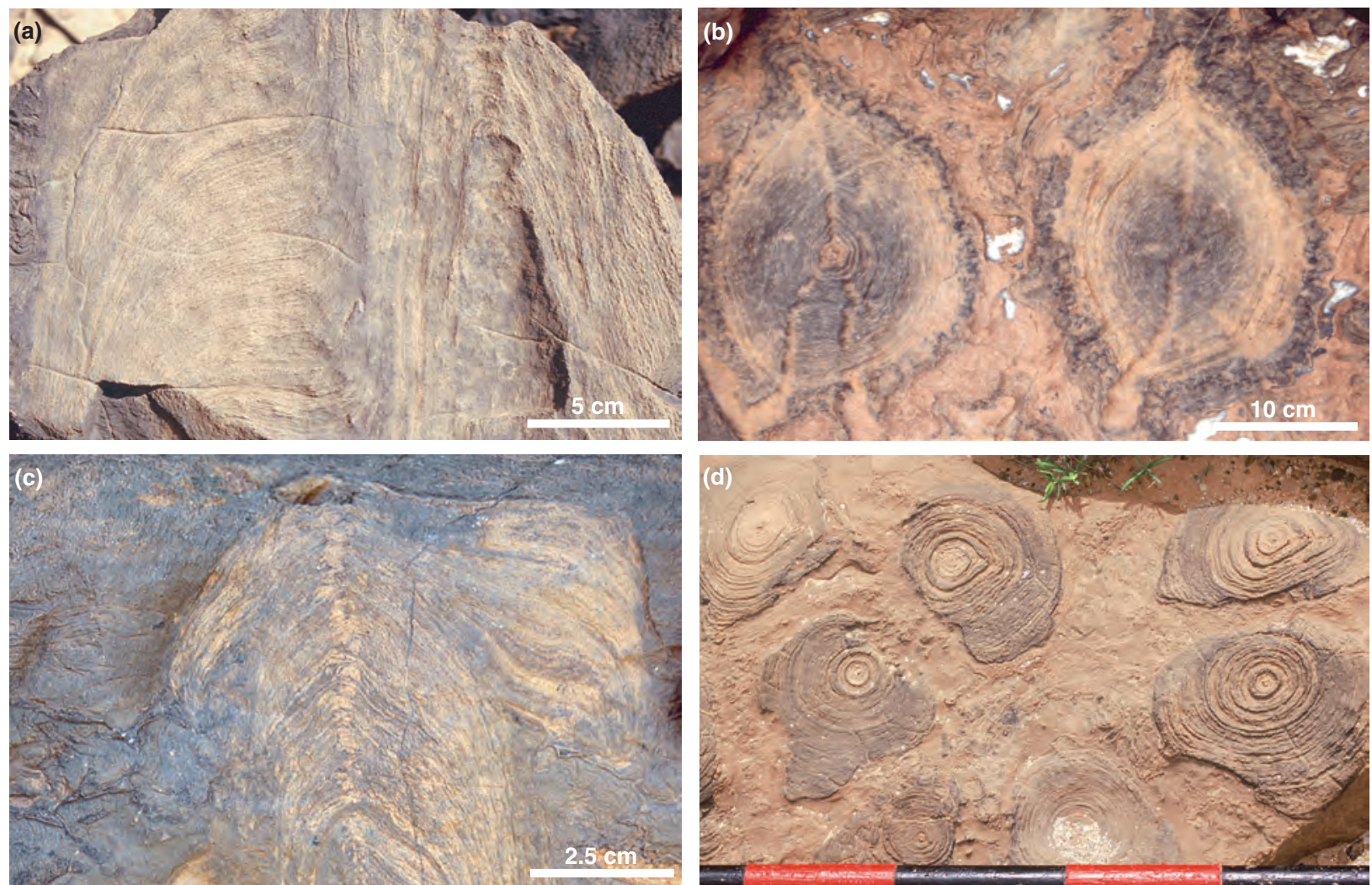

Fig. 6. Morphological features of conical stromatolites. (a) Secondary growth of Conophyton without disruption of initial conical laminae. (b) Elliptical cross section of Conophyton showing irregular thickening of outermost laminae. (c) Delamination of partially lithified Conophyton laminae. (d) Eroded margins of Conophyton indicate exposure to wave action after lithification, but prior to deposition of interstromatolitic material. Jacob staff divisions are $10 \mathrm{~cm}$.

Interstromatolitic regions of Jacutophyton consist exclusively of platy breccia and several generations of precipitated carbonate cement (Fig. 9; see descriptions below). The general absence of breccia between branching elements, and the presence of rare laminae that envelop numerous branches (Fig. 5b), however, suggest that interstromatolitic debris was deposited primarily after the growth of branches.

\section{Branching columnar stromatolites}

Low- to moderate-relief columnar stromatolites comprise several morphotypes of variably branching columnar stromatolites with synoptic relief of no more than a few centimetres (Fig. 8). Branches are typically moderately to highly divergent, producing stromatolites that widen upward. These forms have low to moderate inheritance and produce biostromes composed of numerous columns. Tilemsina divergens (Fig. 8a) and related forms are characterized by irregular unwalled margins of low synoptic relief $(<2 \mathrm{~cm})$ and variably divergent, asymmetric branching. Branching columns of moderate relief include the form-taxa Tungussia confusa (Fig. 8b), Baicalia safia and Baicalia mauritanica (Fig. 8c and d). These stromatolites have columns that widen upward and branch at irregular intervals. Synoptic relief varies from nearly flat (horizontal lamina) to $\sim 8 \mathrm{~cm}$. In the Atar Formation, stromatolites attributable to Tungussia occur only in the inter-reef shaly intervals, whereas Tilemsina and Baicalia both occur as reef elements.

Intercolumnar regions of branching stromatolites vary widely and can contain platy breccia, detrital microspar and several generations of precipitated carbonate cement (see descriptions below). Tilemsina, however, is associated exclusively with fine-grained platy breccia (Fig. 8a), and Tungussia is associated exclusively with detrital microsparitic carbonate (Fig. 8b). By contrast, intercolumnar regions of Baicalia are quite variable, often consisting of a generation 

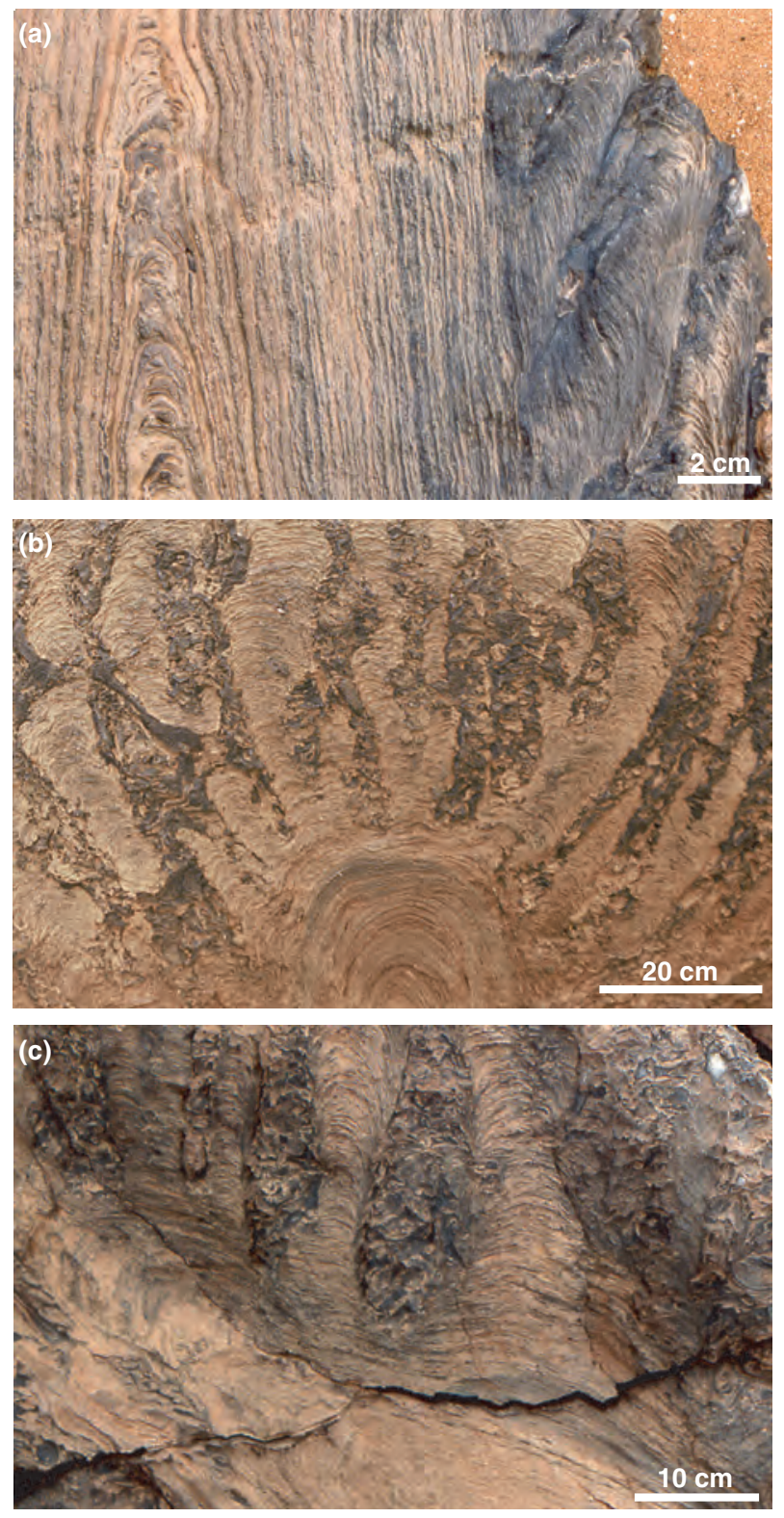

Fig. 7. Development of branching elements on Conophyton. (a) Detail of Jacutophyton sp. showing branch initiation along a single laminae horizon. (b) Divergent branching columns of Tilemsina sp. overgrowing modified top of Conophyton sp. (c) Upward growth of Baicalia sp. above toppled Conophyton sp.

of isopachous carbonate cement followed by deposition of detrital microsparitic carbonate (Fig. 8d).

\section{Interstromatolitic detrital carbonate}

Two distinct forms of interstromatolitic debris occur within the Atar Formation reefs: interstromatolitic breccia and carbonate microspar. Interstromatolitic breccia consists of variably convoluted, platy fragments (Fig. 9a-d) that show distinct lamination and petrographic fabric indistinguishable from that of intact conical stromatolites. Clasts range in size from $1 \times 3 \mathrm{~mm}$ to $7 \times 25 \mathrm{~mm}$ and show variable degrees of hydrodynamic sorting. Coarse-grained debris, which shows the widest range of grain sizes and poor to moderate sorting, occurs exclusively in association with Conophyton and Jacutophyton (Fig. 9a-d). Fine-grained debris shows the most hydrodynamic sorting and is found in association with all stromatolite types, although it is most prevalent in its association with Tilemsina (Fig. 8a). Carbonate microspar is locally abundant as an interstromatolitic element, forming discontinuous, massive to weakly laminated, undulatory beds a few millimetres to $>50 \mathrm{~cm}$ thick. In addition to discontinuous beds, detrital microsparitic carbonate also occurs as later-stage, occasionally geopetal fill in voids formed by platy breccia (Fig. 9b and c).

The lateral distribution of interstromatolitic material within the Atar Formation reefs is extremely variable. Beds of detrital microsparitic carbonate greater than $30 \mathrm{~cm}$ thick can envelop several adjacent Conophyton, yet not extend laterally for more than a few metres. Single Conophyton columns can also be enveloped by detrital microsparitic carbonate at one side and coarse-grained platy breccia at the other. The vertical distribution of interstromatolitic facies is equally as variable, with the margin of a single $1.5 \mathrm{~m}$ tall Conophyton contacting up to five distinct layers of interstromatolitic fill.

\section{Marine cement}

Atar Formation stromatolite reefs contain locally abundant marine cement (up to $25 \%$ of interstromatolitic material). Marine cement forms multilayered isopachous rims within voids defined by interstromatolitic debris (Fig. 9a-d) and, more rarely, along stromatolite edges and the depositional substrate. These first-generation cements are composed entirely of herringbone carbonate. Herringbone carbonate is an unusual carbonate morphology consisting of elongate crystals in which the $C$-axis rotates throughout growth, from parallel to perpendicular to crystal elongation (Sumner \& Grotzinger, 1996a,b), which results in a characteristic sweeping extinction parallel to crystal elongation direction (Fig. 9e-g). 

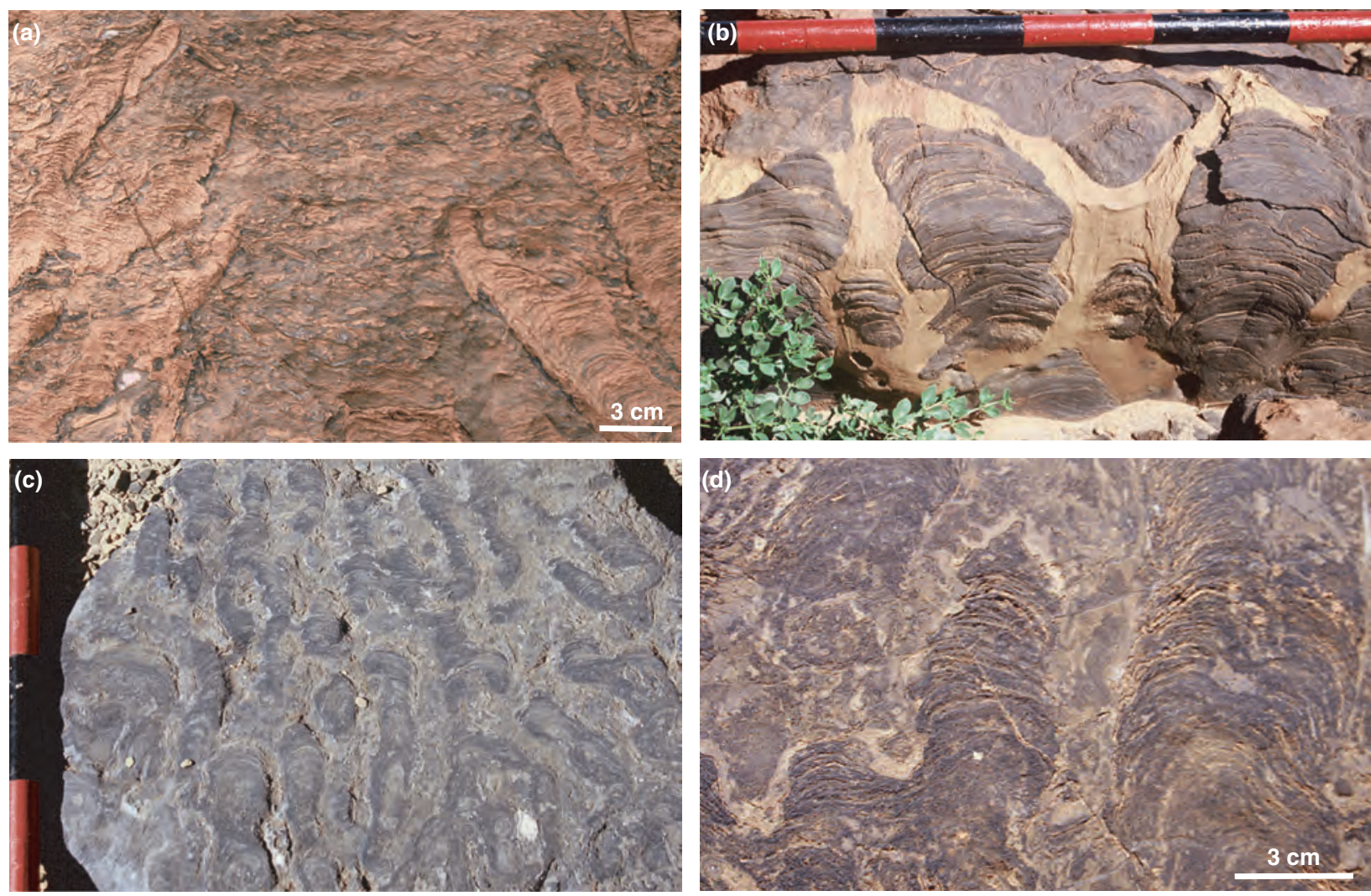

Fig. 8. Branching columnar stromatolites of the Atar Formation. (a) Tilemsina divergens is characterized by low synoptic relief, irregular margins and repeated outward-diverging branching. (b) Irregular branching and upward-broadening columns of Tungussia confusa. Tungussia occurs primarily as small biostromes in inter-reef shales. (c) Strongly clustered, irregular branching of Baicalia in the uppermost R3 reef interval. (d) Irregular branching columns of moderate synoptic relief are represented in the Atar Formation by Baicalia safia, which preserves irregular coniform laminae, and Baicalia mauritania (shown here), which preserves domal laminae in cross-section.

This unusual mode of crystal growth is most prevalent as a seafloor precipitate in the Archaean and as a void-filling cavity cement in younger successions (de Wet et al., 1999), and has been attributed to both the presence of ferrous iron under conditions of regional anoxia (Sumner \& Grotzinger, 1996b) and to the presence of locally elevated concentrations of dissolved inorganic carbon derived from remineralized organic matter (Tourre \& Sumner, 2000). In the Mesoproterozoic, extensive precipitation of herringbone carbonate is generally restricted to basinal facies (Kah et al., 1999b), with its presence in platform deposits closely associated with transgressive surfaces (Kah et al., 2006). Later stage void-fill typically includes a single layer of isopachous bladed calcite, coarse blocky calcite spar and ferroan dolomite cement (Fig. 9a-d).

\section{PARASEQUENCE DEVELOPMENT OF STROMATOLITE BIOSTROMES}

Superpositional relationships between and among reef elements can be used to determine the relative timing of deposition (or growth) of elements, as well as the morphology of the sedimentary substrate. Combined, these relationships permit a detailed evaluation of changes in accommodation space during development of the Atar Formation biostromes. The cratonal deposition regime represented by the Atar Formation biostromes, and the Atar Group as a whole (BertrandSarfati \& Moussine-Pouchkine, 1988), suggests that changes in accommodation space were most likely driven by changes in sea level. In terms of stromatolite development, sea-level changes would result primarily in changes in ambient 

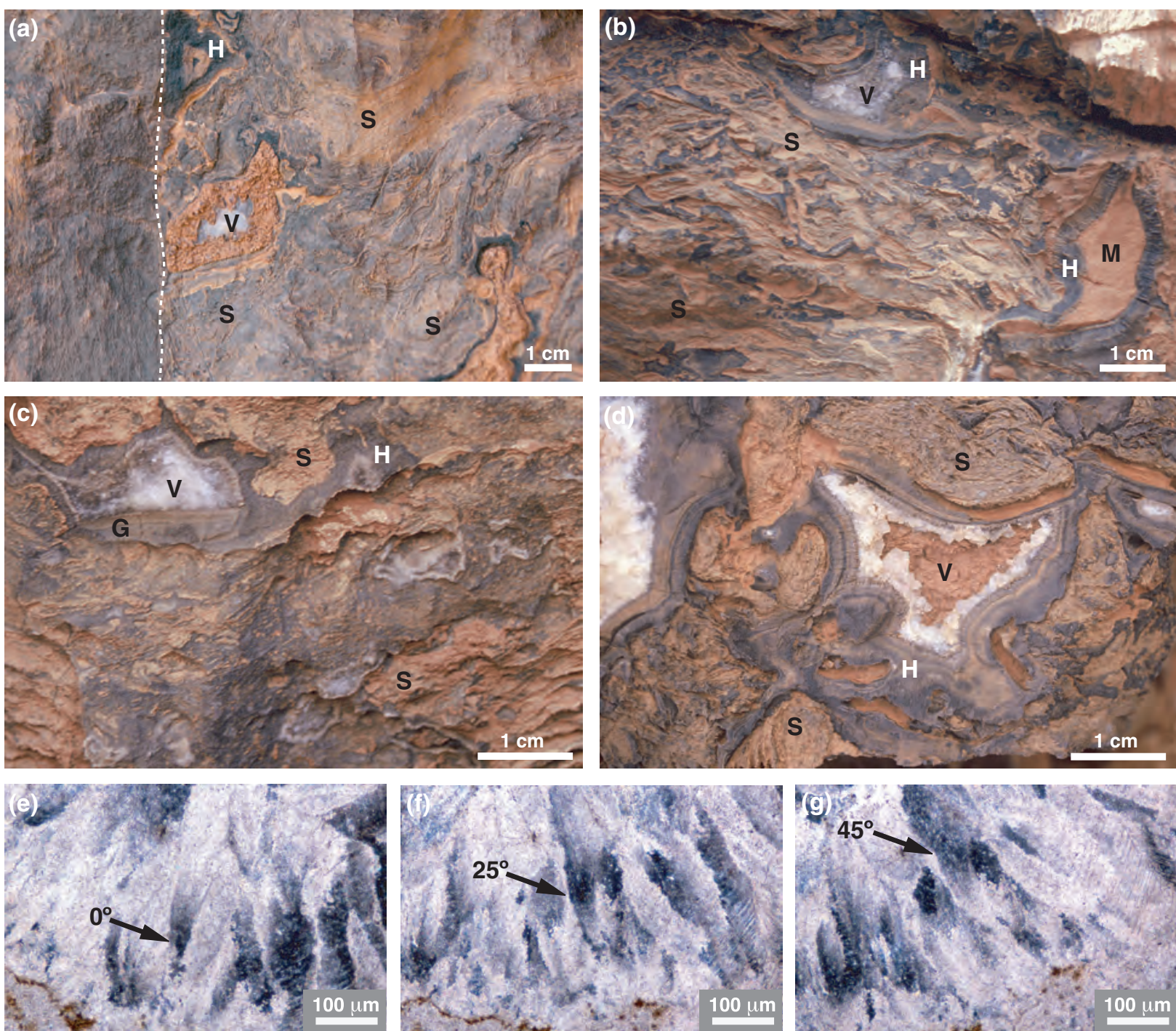

Fig. 9. Interstromatolitic material typical of Conophyton-Jacutophyton intervals. (a) Relationship between Conophyton (left of dotted line) and interstromatolitic material, including distorted stromatolitic debris (S), herringbone carbonate cement $(\mathrm{H})$ and void-filling cement (V). (b) Void fills show several discrete generations of deposition. The first generation of cement always consists of marine herringbone carbonate cement; later generations include one or more of the following: microsparitic crystal silt (M), blocky white spar, or ferroan dolomite cement. (c) The presence of geopetal fill (G) implies that interstromatolitic void space remained open to fluid and sediment transport even after precipitation of marine herringbone cement. (d) Late-stage calcitic and dolomitic void fills imply significant porosity of interstromatolitic regions well after deposition and perhaps into burial environments. (e-g) The petrographic expression of herringbone carbonate, which shows sweeping extinction along the crystal axis, results from a rotation of the $c$-axis during crystal growth.

water energy and the position of storm and fair weather wave-base.

On the scale of a single biostromal package (interpreted to represent a third-order sequence), sea-level history is fairly straightforward. The base of each biostrome (R1-R3) is marked by the presence of a thin, discontinuous interval of branching columnar stromatolites, typically of the form genus Tilemsina, whose irregularly divergent branching, low synoptic relief, and unwalled column structure indicate that accretion of stromatolitic laminae kept pace with deposition of hydrodynamically well-sorted, fine-grained platy breccia. These thin, discontinuous, highenergy beds are interpreted as transgressive deposits. By contrast, the main body of the 
reef consists primarily of Conophyton, whose steep-sided walls, synoptic relief and large heightto-width ratio indicate deposition in a lowenergy environment with little or no sedimentary influx. Such environments are typical of marine highstands, when accommodation space is at its greatest and backstepping of the shoreline inhibits sediment influx into the basin. Finally, each reef interval concludes with either a regional pavement of broken Conophyton (R1, R2) or the appearance of irregularly branching elements, each of which can be interpreted as reflecting a loss in accommodation space associated with either sealevel fall or aggradational stromatolitic growth (Bertrand-Sarfati \& Moussine-Pouchkine, 1988).

Within each third-order package, however, unusual vertical and lateral juxtapositions of stromatolite forms suggest a much more complex developmental history. Detailed superpositional relationships between and among reef elements, however, suggest that the complex juxtaposition of stromatolite forms can be interpreted in terms of parasequence-scale (fourth to fifth order) changes in relative sea level. The most common and conspicuous elements of parasequences in the Atar Formation reef are Conophyton. These stromatolites represent dominantly subtidal (beneath storm wave-base; Donaldson, 1976; BertrandSarfati \& Moussine-Pouchkine, 1985; Kah et al., 2006) stromatolite nucleation during marine transgression and upward growth throughout transgression and early highstand (Fig. 10a, V1-V6). Rare variation in Conophyton morphology, such as the presence of Conophyton with elliptical cross sections, irregular margins and occasional branch development (Fig. 6b; Conophyton jacqueti; Bertrand-Sarfati \& Moussine-Pouchkine, 1999) may represent the presence of low-energy currents during Conophyton growth. The trajectory of parasequence formation, however, and the resultant complexity of individual parasequence (Fig. 10; see below) depends critically upon the position of Conophyton with respect to wave base, the magnitude of parasequence-scale sea-level changes, and the lithification history of the Conophyton.

If Conophyton tops are sufficiently beneath wave base, aggradational growth may continue even during falls in relative sea level, resulting in Conophyton with the greatest synoptic relief. Alternatively, upward growth may simply terminate and become a nucleus for later Conophyton development (Figs 10a-c, V1 and 6a). Parasequence complexity increases dramatically if, during falls in relative sea level, Conophyton tops are subjected to subaerial exposure or increased wave energy. High-energy storm events or prolonged subaerial exposure may topple cones, forming a substrate for subsequent microbial growth or terminating parasequence development (Figs 10b, $\mathrm{V} 2$ and $4 \mathrm{a}$ and b). Wave energy may also deeply erode fully lithified cones (Fig. 6d) or delaminate poorly lithified outer margins of the cones (Fig. 6c). In the former case, upon subsequent rise in sea level, stromatolite growth may resume, with stromatolite morphologies (conical vs. branching) reflecting the hydrodynamic conditions within the environment (Fig. 10b, V2). In the latter case, stromatolitic debris may be transported, hydrodynamically sorted and deposited in interstromatolitic regions (Fig. 10b, V3), with lowstand nucleation and growth of stromatolites such as Tilemsina in high-energy environments between adjacent Conophyton (Fig. 10b, V4). During subsequent rises in sea level, nucleation of new Conophyton may occur on either exposed cone tops or on interstromatolitic detritus.

Additional complexity of parasequences occurs when falls in relative sea level expose Conophyton to wave energy, but interstromatolitic detritus is generally absent. In this case, disruption of the outermost laminae of living Conophyton (i.e. those with unlithified outer margins) by wave energy would result in Conophyton encircled by partially delaminated microbial elements that, in turn, would form initial substrate for the petaloid branching elements characteristic of Jacutophyton (Fig. 10b, V5). Laterally adjacent non-living or more heavily lithified Conophyton may experience either no delamination, or more extreme erosion (Fig. 6d) during lowstand. The absence of platy breccia between petaloid branches suggests that wave energy may not be sufficient to create or transport significant breccia, although some breccia may be deposited during latest lowstand. In the Atar Formation biostromes, Jacutophyton parasequences show the most variability upon subsequent sea-level rise, with new Conophyton nucleating adjacent to Jacutophyton, initiating atop the central cone of Jacutophyton (Figs 10c, V5a and 11a), or developing directly on Jacutophyton branches (Figs 10c, V5b and 11b). In rare cases, subsequent growth of branching stromatolites (Fig. 10c, V5c) suggests sea-level rise insufficient to place microbial growth beneath wave-base.

Finally, if falls in relative sea level expose only the tip of Conophyton to wave energy, either because of the position of wave-base relative to stromatolites or the presence of abundant detrital 
(a) Parasequence 1 - sea level rise
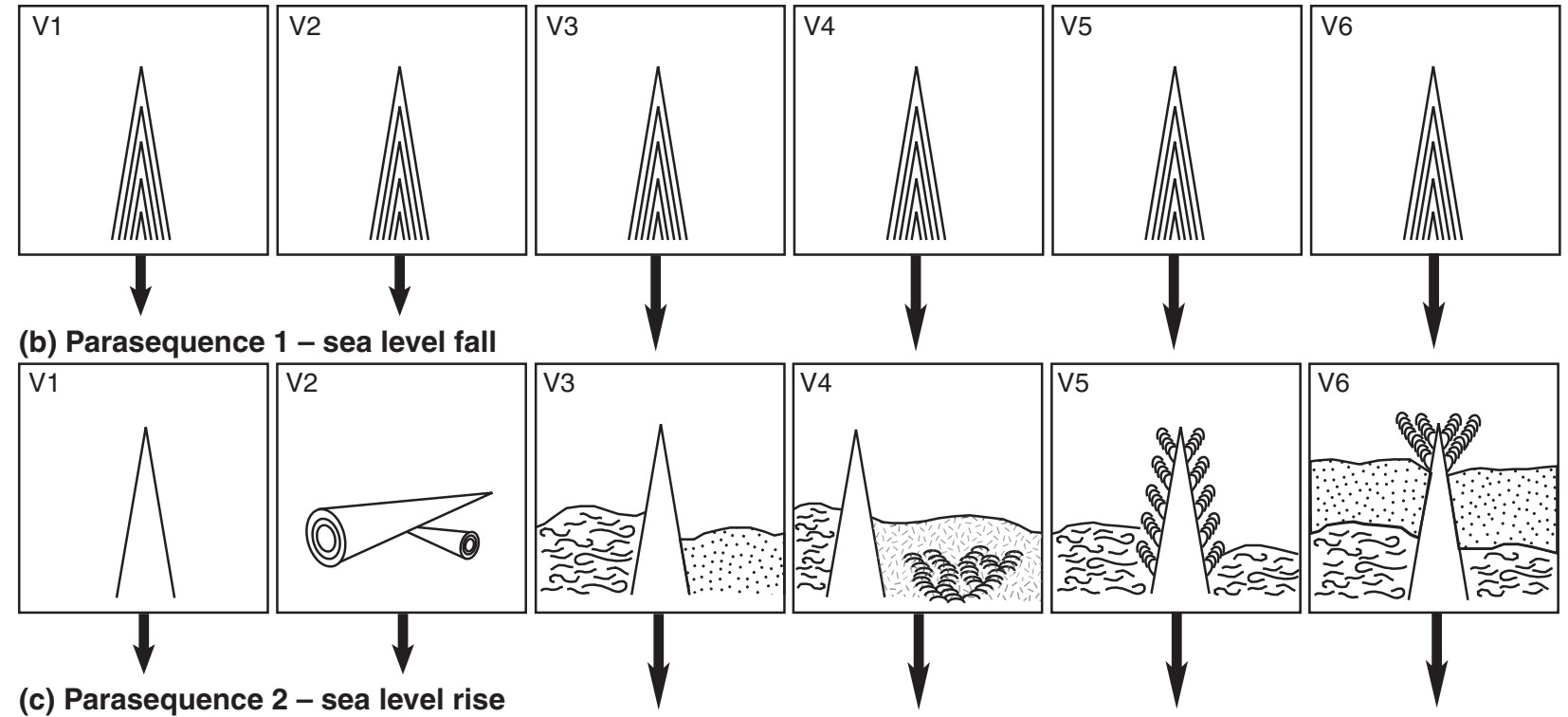

(c) Parasequence 2 - sea level rise
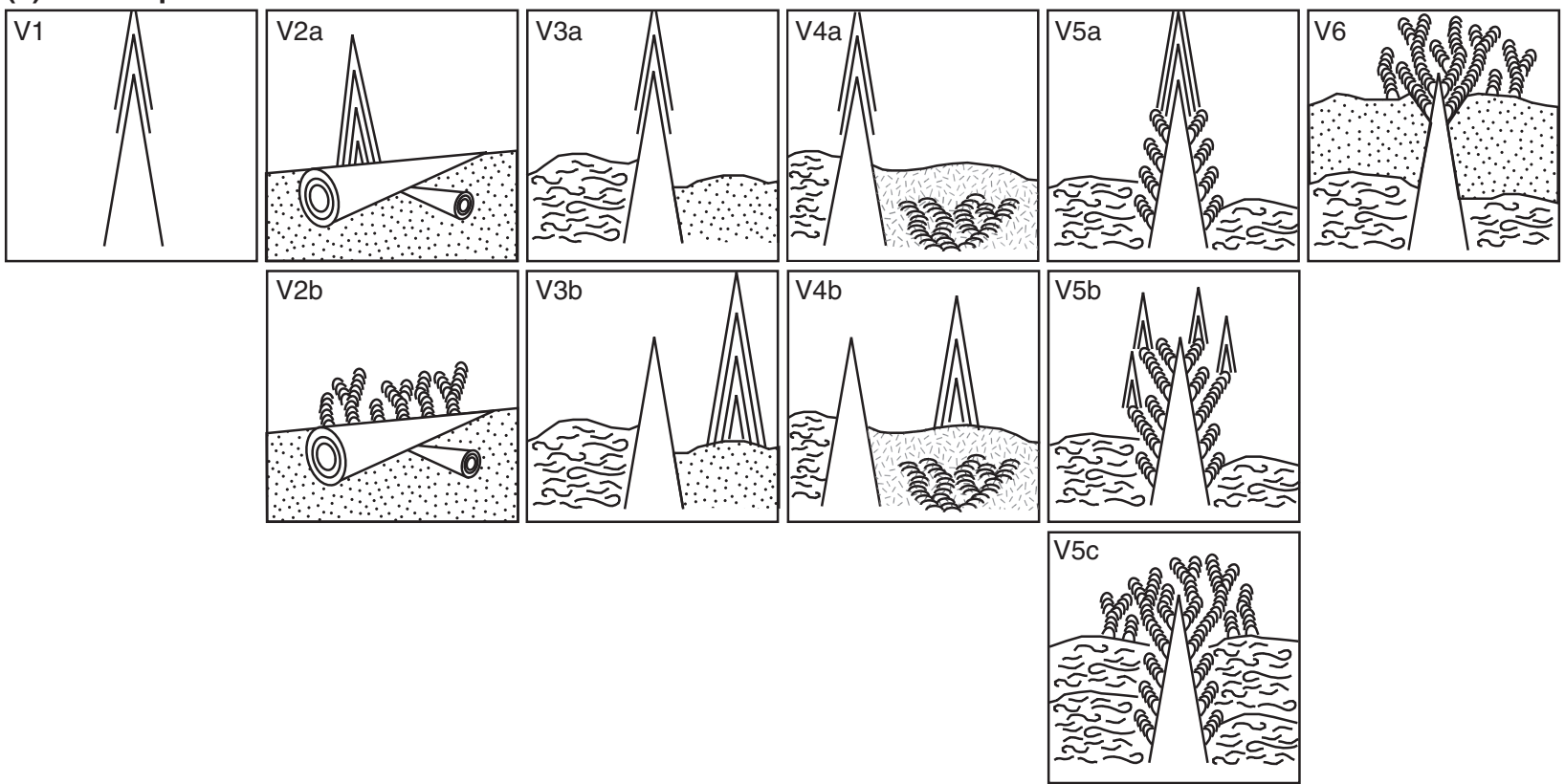

Fig. 10. Parasequence development of the Atar reefs. (a) Parasequences initiate upon sea level rise with the nucleation and growth of Conophyton (V1-V6). (b) During sea level fall, accretion of cones is halted (V1) and cones are subject to erosion or toppling (V2), partial burial by interstromatolitic material (stromatolitic debris or detrital microspar; V3), or development of lowstand phase stromatolites, including adjacent bioherms of Tilemsina (V4), concentric branches of Jacutophyton sahariensis. (V5), or restricted growth of irregular columnar branches (Baicalia or Tilemsina; V6). (c) Subsequent sea level rises, of sufficient magnitude to place the substrate beneath wave base, results in reinitiation of coniform growth atop previous upright or toppled Conophyton or Jacutophyton (V1-V5a), nucleation of new Conophyton (V3b-V4b), and development of Conophyton from branching elements of Jacutophyton (V5b). If, during subsequent sea level rises, the substrate remains within wave base, stromatolite growth is marked by development of irregular branching columns of Tilemsina and Baicalia (V6, V2b, V5c).

material, branching can develop at the tops of living cones (Fig. 10b, V6). During subsequent sea-level rise, branching can develop into new cones, or into biostromes of irregularly branching columns depending on the hydrodynamic state of the environment. In the Atar Formation, this scenario is observed in the formation of Tilemsina on cone tops in the R1 and R2 biostromes (Fig. 7b), in the appearance of branches on Conophyton jacqueti in the R3 biostrome 

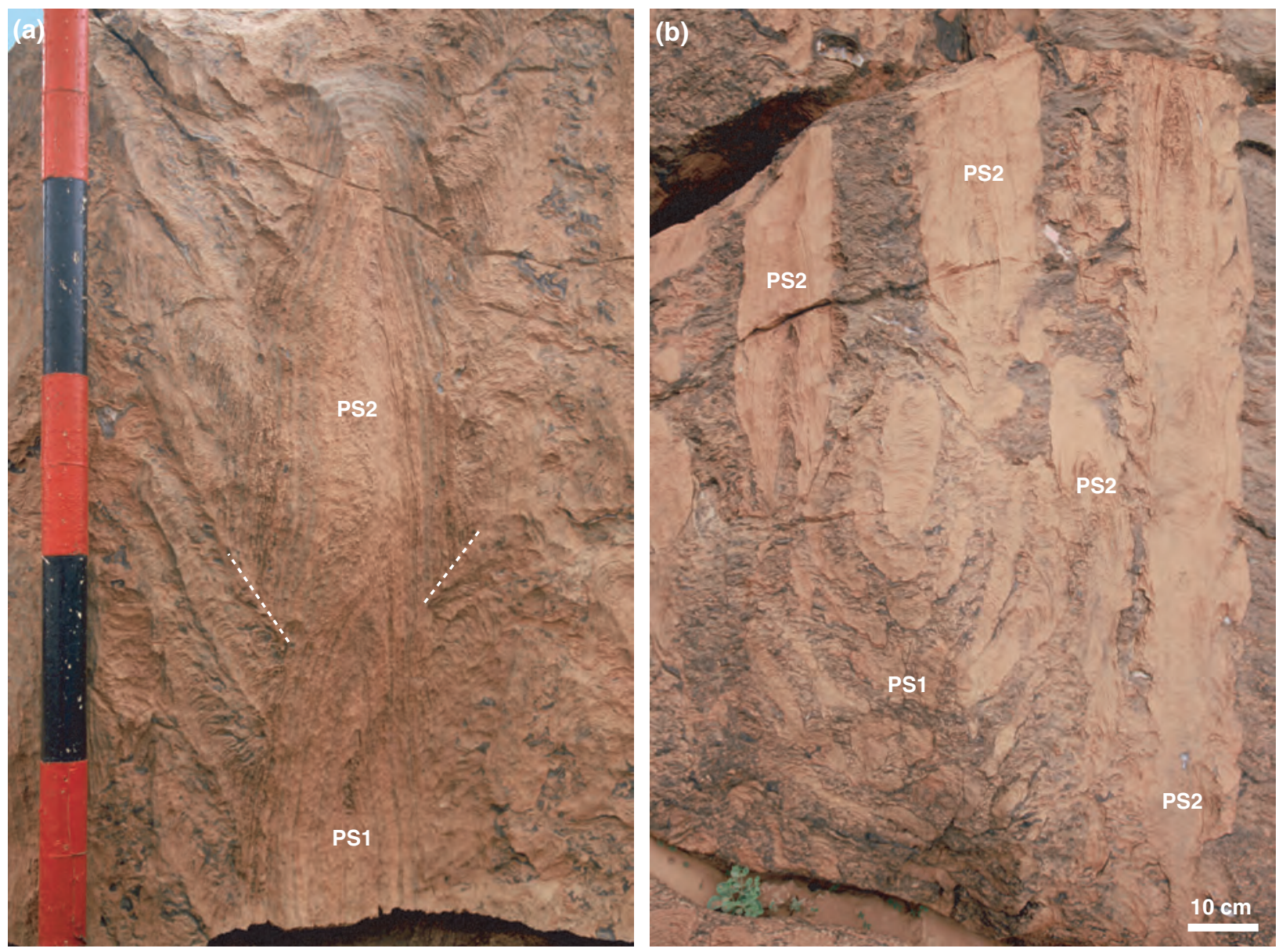

Fig. 11. Stacked parasequences in Jacutophyton sahariensis. (a) Branching elements of Jacutophyton sahariensis (PS1) are onlapped by conical laminae during initial development of a second-generation Jacutophyton (PS2) whose central cone nucleated directly atop the central cone of PS1. Jacob staff is marked in $10 \mathrm{~cm}$ intervals. (b) Several branching elements of J. sahariensis (PS1) develop into central cones and form the base of a second generation of Jacutophyton (PS2).

(cf. Bertrand-Sarfati \& Moussine-Pouchkine, 1999) and in the gradational transition from Conophyton to Baicalia Safia and Baicalia mauritanica at the top of the R3 biostrome (Fig. 10c, V6).

The extraordinary variability of biostromal parasequences in the Atar Formation results, in part, from the vertically and laterally variable deposition of interstromatolitic material. Outcrop exposures record the small spatial scales (a few to a few tens of metres laterally, a few centimetres to tens of centimetres vertically) of variability, but do not permit detailed mapping of interstromatolitic debris. Laterally variable deposition probably results from the cratonal, regionally low-relief environments of the Atar Group (Bertrand-Sarfati \& Moussine-Pouchkine, 1988), wherein variation in water energy (e.g. channelling of tidal surges, relief of the substrate), localized production of water-column carbonate (e.g. whitings) and restricted production of stromatolitic breccia (e.g. delamination of nonlithified cones) act together to produce a mosaic of interstromatolitic facies.

Platy breccia facies are episodically stabilized by the precipitation of herringbone carbonate cement. Rarely, herringbone cement is observed coating both stromatolites and the sedimentary substrate. In these cases, the thickness of the stromatolitic component of a single parasequence (i.e. the height of a Conophyton) is typically $100-150 \mathrm{~cm}$, yet the thickness of the detrital component may vary from only a few centimetres to tens of centimetres in thickness. As a result, parasequence boundaries can show dramatic lateral variability. Furthermore, if the presence of herringbone carbonate indicates transport of basinal waters onto 
the shelf during marine transgression (Kah et al., 2006), thick encrustations of herringbone carbonate within coarse-grained platy breccias (Fig. 9d) suggest that stabilization of the sedimentary substrate occurred over multiple parasequences. This scenario is supported by the presence of microsparitic detrital carbonate within herringbone-lined voids, which probably represents the winnowing of fine-grained detritus through a highly permeable substrate. If substrate stabilization is protracted through several sea-level cycles, it is possible that some parasequences within the Atar Formation reefs may have experienced significant post-depositional modification.

\section{DISCUSSION}

\section{Idealized model for reef growth}

Taken together, the development of Atar Formation biostromes on a low-relief, cratonal platform (Bertrand-Sarfati \& Moussine-Pouchkine, 1988), the laterally variable thicknesses of parasequences and the possible post-depositional modification of parasequences make deciphering the precise architecture of the Atar reefs difficult. Our understanding of parasequence development, however, allows construction of an idealized model for biostrome development that is a function of (1) regional platform geometry, which controls the position of the substrate relative to wave base and the total accommodation space available for stromatolite growth, and (2) the magnitude of parasequence scale (fourth or fifth order) sea-level changes, which act to modify total accommodation space and the position of wave base.

At distal craton margins, the steeper gradient of the substrate and potentially greater rates of subsidence should result in available accommodation space that is large relative to parasequence-scale sea-level changes. In this scenario, upward growth of conical stromatolites would remain uninterrupted by small-scale changes in sea level and low water energy would prohibit growth of branching stromatolites and the production and deposition of interstromatolitic detritus, resulting in a stromatolite tract that is dominated by high relief Conophyton (cf. Dismal Lakes reef, Donaldson, 1976; Kah et al., 2006). Branching stromatolites such as Baicalia safia and Baicalia mauritanica or the incipient branching of Conophyton jacqueti would form only with large magnitude falls in sea level or with the continued aggradation of stromatolite growth, which could potentially bring the biostrome top above wave base. Jacutophyton, which requires a significant fall in eustatic sea level and exposure of entire cones to wave energy, would not be expected to form.

By contrast, over much of the cratonal platform, intermediate water depths and low depositional relief should result in environments in which parasequence-scale changes in sea level would exert a greater influence over stromatolite form, resulting in greater variability of stromatolite morphology within biostromes. In these regions, total accommodation space available for stromatolite growth relative to the magnitude of parasequence-scale sea-level changes is critical in the distribution of different stromatolite morphologies. First, larger magnitude sea-level rises would bring more of the cratonal platform beneath wave base, resulting in widespread development of conical stromatolites. Similarly, smaller magnitude sea-level changes would result in restricted spatial development of conical stromatolites. Second, during eustatic falls in sea level, deeperwater portions of the platform would experience less wave energy (perhaps episodic wave energy if between fair weather and storm wave-base), resulting in biostromes dominated by Conophyton and Jacutophyton. Similarly, shallower-water portions of the shelf would experience wave energy sufficient to produce quantities of detrital material. In these regions, the biostrome would be dominated by Jacutophyton and the branching form Tilemsina, with sparse Conophyton reflecting conical forms that were well-lithified at the time of sea-level fall. Throughout these platformal regions, unusual juxtaposition of stromatolite forms results not from penecontemporaneous growth, as previously inferred (Bertrand-Sarfati \& Moussine-Pouchkine 1985, 1999), but from laterally adjacent growth during distinct phases of sea-level cycles.

Shallowest regions of the craton should also contain a third, distinct stromatolite tract. In these regions, low overall accommodation space will result in deposition controlled mainly by parasequence-scale eustatic sea-level changes. Biostrome development should be absent except during brief periods of cratonal inundation and should be dominated by low-relief, irregularly branching stromatolite forms. In fact, high water energy might fully preclude development of Conophyton, with coniform growth represented only by the low-relief conical laminae of Baicalia safia. Low synoptic relief of stromatolites and 
high rates of deposition of interstromatolitic debris will also result in parasequences that preserve much less lateral variability in thickness. When cratonal inundation is insufficient for stromatolite development, biostromes should be replaced by thin parasequences characterized by fine-grained detrital carbonate and/or flatlaminated microbialites, with or without evaporite lithologies.

\section{Implications for basin geometry and development of Atar Formation reefs}

In light of the idealized model described above, several generalizations can be made regarding environments of deposition of the Atar Formation biostromes. The stratigraphically lower R1 and R2 biostromes record a complex juxtaposition of Conophyton, Jacutophyton and Tilemsina, and parasequences show lateral variability in thickness from a few centimetres to $<2 \mathrm{~m}$ (i.e. the total synoptic relief of Conophyton present in the interval), with an average parasequence thickness of $60-70 \mathrm{~cm}$. These reef intervals are interpreted as having formed in intermediate water depths along a broad expanse of the stable, West African craton. By contrast, the stratigraphically higher R3 interval preserves a very different stromatolite structure, which is dominated by large, high-relief Conophyton and typically lacks Jacutophyton and Tilemsina. Branching forms are rare except for several horizons containing the incipient branching Conophyton jacqueti and an upper interval dominated by Baicalia safia and Baicalia mauritanica. The abundance of large Conophyton and relative lack of Jacutophyton suggests that accommodation space during deposition of the R3 interval was sufficiently great that parasequence-scale changes in sea level were unable to expose stromatolite bases to wave energy. Gradual, rather than abrupt transitions to branching forms suggest, instead, that stromatolite aggradation was the main factor involved in decreasing accommodation space. Finally, recent field exploration in central and eastern Mauritania has demonstrated that Atar Formation bioherms are laterally replaced by discontinuous thin (typically $<5 \mathrm{~m}$ thick) stromatolitic intervals of low-relief, irregularly coniform to columnar stromatolites with possible affinities to Baicalia safia and Baicalia mauritanica and by thin (15-35 cm thick) laterally continuous parasequences of fine-grained detrital carbonate (Tourist Formation). Lithologies of central and eastern Mauritania strongly suggest a proximal cratonal setting, where development of stromatolitic build-ups is restricted to brief periods of cratonal inundation.

The parasequence structure throughout the Atar Formation stromatolite buildups suggests that it is unlikely that these buildups formed a regional barrier to wave or current energy, although stromatolites may have served as local baffles to water energy and sediment transport. The interpretation that Atar Formation biostromes did not form regional hydrodynamic barriers differs markedly from previous interpretation of these biostromes as basin-forming, constructional high-relief reefs (Bertrand-Sarfati \& Moussine-Pouchkine, 1992, 1999; Moussine-Pouchkine \& Bertrand-Sarfati, 1997). In the constructional reef model, based in large part on data collected in easternmost exposures of the Atar Group (Hank Group in Algeria), near the tectonic edge of the West African craton, stromatolite biostromes are interpreted to have stood $20-25 \mathrm{~m}$ above the seafloor, in water depths >50m (Bertrand-Sarfati \& MoussinePouchkine, 1988). Reef margins dropped steeply at their edges, producing protected depressions devoid of sedimentary input during reef growth. The resultant platform geometry was one of stromatolitic platforms separated by rimmed depressions 15-20 m deeper than the platforms (Bertrand-Sarfati \& Moussine-Pouchkine, 1992). During sea-level fall, reef tops became exposed subaerially, shedding debris into intrashelf basins. Over the course of three sea-level cycles, intrashelf basins were filled with shale, marls and reef debris (Bertrand-Sarfati \& MoussinePouchkine, 1992).

\section{SUMMARY AND CONCLUSIONS}

1 The Atar Formation (Mesoproterozoic Atar Group, Taoudeni Basin, Mauritania) preserves a series of three stromatolite biostromal complexes. Biostromes initiated during successive third-order rises in sea level and terminated with the filling of available accommodation space, either via an abrupt fall in eustatic sea level (R1, R2) or the continued aggradational growth of stromatolitic facies (R3). In contrast to other stromatolitic complexes, the Atar Formation biostromes lack unambiguous, largescale changes in geometry (i.e. vertical stacking of expanding, contracting, or backstepping reef 
packages) associated with changes in sea level and accommodation space. They also preserve a peculiar juxtaposition of conical and branching stromatolite forms, which typically occur in distinct depositional environments.

2 Careful assessment of superpositional relationships among stromatolitic elements indicates that the diversity of stromatolite morphologies in the Atar Formation can readily be explained via parasequence-scale sea-level changes and the incomplete and laterally discontinuous filling of accommodation space. Each parasequence is represented by subtidal nucleation and growth of conical stromatolites during initial transgression and sea-level highstands, followed by a variety of complex interactions between production and deposition of interstromatolitic debris and stromatolite growth during sea-level lowstands. The character of lowstand deposition is controlled by the amount of available accommodation space and wave energy, and the unusual juxtaposition of stromatolite forms reflects lateral infilling of accommodation space at different times under very different environmental conditions. In this scenario, the enigmatic stromatolite form Jacutophyton spp. represents a single depositional parasequence, wherein transgression and sea level highstand are marked by growth of the central cone, and sea level lowstand is marked by growth of superimposed branching columns and deposition of interstromatolitic debris.

3 Interpretation of the parasequential growth of Atar stromatolites allows construction of an idealized model for biostrome development that is a function of regional platform geometry, which controls the position of the substrate relative to wave base and the total accommodation space available for reef growth, and the magnitude of parasequence-scale (fourth or fifth order) sea-level changes, which act to modify total accommodation space and the position of wave base. In light of this model, the parasequence structure of the Atar Formation suggests that it is unlikely that stromatolite buildups formed a regional barrier to wave or current energy. This interpretation of Atar Formation biostromes as stacked, low-relief depositional parasequences differs markedly from previous interpretation of these biostromes as constructional, high-relief reefs that played an active role in development of inter-reef basins.

\section{ACKNOWLEDGEMENTS}

Field work was supported by grants from the National Geographic Society and the National Science Foundation (EAR-0106089). We thank Janine Sarfati and Alexis Moussine-Pouchkine for introducing us to the Atar Group during an IGCP Project 380 field trip in 1998 and gratefully acknowledge them for their steadfast support and aid in expediting our 2003 field season. We also acknowledge all participants of the 1998 IGCP field trip, and especially Bob Ginsburg, for enthusiastic discussion of stromatolite morphologies. Finally, many thanks go to Mohammed Lemin, Malik, Mohammed and Maloud for their assistance in the field. Thoughtful reviews by Hans Hofmann and Miriam Andres helped to improve the clarity of the manuscript.

\section{REFERENCES}

Andres, M.S. and Reid, R.P. (2006) Growth morphologies of modern marine stromatolites: a case study from Highborne Cay, Bahamas. Sed. Geol., 185, 319-328.

Bartley, J.K., Kah, L.C., McWilliams, J.L. and Stagner, A.F. (2007) Carbon isotope chemostratigraphy of the Mesoproterozoic Avzyan Formation (Southern Urals, Russia): signal recovery in a fold-and-thrust belt. Chem. Geol., 237, 211-232.

Bartley, J.K., Semikhatov, M.A., Kaufman, A.J., Knoll, A.H., Pope, M.C. and Jacobsen, S.B. (2001) Global events across the Mesoproterozoic-Neoproterozoic boundary: $\mathrm{C}$ and $\mathrm{Sr}$ isotopic evidence from Siberia. Precambrian Res., 111, 165-202.

Benan, C.A.A. and Deynoux, M. (1988) Facies analysis and sequence stratigraphy of Neoproterozoic platform deposits in Adrar of Mauritania, Taoudeni Basin, West Africa. Geol Rundsch., 87, 283-330.

Bertrand-Sarfati, J. (1972) Paléoécologie de certains stromatolites en récifs des formations du Précambrien supérieur du groupe d'Atar (Mauritanie, Sahara occidental): création d'espéces nouvelles de ces récifs. Palaeogeogr. Palaeoclimatol. Palaeoecol., 11, 33-63.

Bertrand-Sarfati, J. (1983) Les stromatolites anciens, mechanisms de croissance, role des micro-organismes et de l'environment. J. Rech. Ocean., 8, 71-89.

Bertrand-Sarfati, J. and Moussine-Pouchkine, A. (1983) Platform to basin facies evolution: the carbonates of the late Proterozoic (Vendian), Gourma, West Africa. J. Sediment. Petrol., 53, 275-293.

Bertrand-Sarfati, J. and Moussine-Pouchkine, A. (1985) Evolution and environmental conditions of the Conophyton associations in the Atar Dolomite (Upper Proterozoic, Mauritania). Precambrian Res., 29, 207-234.

Bertrand-Sarfati, J. and Moussine-Pouchkine, A. (1988) Is cratonic sedimentation consistent with available models? An example from the Upper Proterozoic of the West African craton. Sed. Geol., 58, 255-276. 
Bertrand-Sarfati, J. and Moussine-Pouchkine, A. (1992) Formation et comblement d'une depression intraplateforme engendree par la croissance d'un biostrome stromatolitique, Proterozoique superieur, Sahara algerien. CR Acad. Sci. Montrouge, 315, 837-843.

Bertrand-Sarfati, J. and Moussine-Pouchkine, A. (1999) Mauritanian microbial buildups: Meso-Neoproterozoic stromatolites and their environment; six days field trip on the Mauritanian Adrar. Assoc. Sediment. Fr., 31, 1-103.

Bertrand-Sarfati, J. and Trompette, R. (1976) Use of stromatolites for intrabasinal correlation; example from the late Proterozoic of the northwestern margin of the Taoudenni Basin. In: Stromatolites (Ed. M.R. Walter). Elsevier, Amsterdam, pp. 517-522.

Bertrand-Sarfati, J., Moussine-Pouchkine, A. and Ait Kaci Ahmed, A. (1996) Subdivisions stratigraphiques nouvelles dans la couverture néoprotérozoique au Nord-Est du basin de Taoudenni (Algérie). In: Géodynamique du craton ouest africain central et oriental: héritage et évolution post-panafricains (Eds L. Bitam and J. Fabre). Serv. Geol. Algérie, 1996, 63-90.

Bertrand-Sarfati, J., Moussine-Pouchkine, A. and Caby, R. (1987) Les correlations du Protérozoique au Cabrien en Afrique de l'Ouest: nouvelle interprétation géodynamique. Bull Soc. Géol. Fr., 3, 855-865.

Bertrand-Sarfati, J., Moussine-Pouchkine, A., Affaton, P., Trompette, R. and Bellion, Y. (1991) Cover sequences of the West African Craton. In: The West African Orogens and Circum-Atlantic Correlatives (Eds R.D. Dallmeyer and J.P. Lecorche). Springer-Verlag, Berlin, pp. 65-82.

Bertrand-Sarfati, J., Moussine-Pouchkine, A., Amard, B. and Ait Kaci Ahmed, A. (1995) First Ediacaran fauna found in western Africa and evidence for an Early Cambrian glaciation. Geology, 23, 133-136.

Black, R. and Fabre, J. (1983) A brief outline of the geology of West Africa. In: Afrique de l'Ouest: introduction geologique et termes stratigraphique (Ed J. Fabre). Pergamon, Oxford, pp. 17-26.

Clauer, N. (1976) Géochimie isotopique du strontium des milieux sédimentaires: application a la geochronology de la couverture du craton ouest-africain. Mem. Sci. Geol., Strasbourg, 45, 1-256.

Clauer, N. (1981) Rb-Sr and K-Ar dating of Precambrian clays and glauconites. Precambrian Res., 15, 331-352.

Clauer, N. and Deynoux, M. (1987) New information on the probable isotopic age of the late Proterozoic glaciation in West Africa. Precambrian Res., 37, 89-94.

Clauer, N., Caby, R., Jeanette, D. and Trompette, R. (1982) Geochronology of sedimentary and metasedimentary Precambrian rocks of the West African craton. Precambrian Res., 18, 53-71.

Cloud, P.E. and Semikhatov, M.A. (1969) Proterozoic stromatolite zonation. Am. J. Sci., 267, 1017-1061.

De Wet, C.B., Dickson, J.A.D., Wood, R.A., Gasworth, S.B. and Frey, H.M. (1999) A new type of shelf margin deposit: rigid microbial sheets and unconsolidated grainstones riddled with meter-scale cavities. Sed. Geol., 128, 13-21.

Donaldson, J.A. (1976) Palaeoecology of conophyton and associated stromatolites in the Precambrian Dismal Lakes and Rae groups, Canada. In: Stromatolites (Ed. M.R. Walter). Elsevier, Amsterdam, pp. 523-534.
Dupraz, C. Pattisina, R. and Verrecchia, E.P. (2006) Translation of energy into morphology: simulation of stromatolite morphospace using a stochastic model. Sed. Geol. 185, 185-203.

Emery, D. and Myers, K. (1996) Sequence Stratigraphy. Blackwell, Oxford, UK.

Fairchild, I.J., Marshall, J.D. and Bertrand-Sarfati, J. (1990) Stratigraphic shifts in carbon isotopes from Proterozoic stromatolitic carbonates (Mauritania): influences of primary mineralogy and diagenesis. Am. J. Sci., 290-A, 46-79.

Frank, T.D., Kah, L.C. and Lyons, T.W. (2003) Changes in organic matter production and accumulation as a mechanism for isotopic evolution in the Mesoproterozoic ocean. Geol. Mag., 140, 397-420.

Furniss, G., Rittel, J.F. and Winston, D. (1998) Gas bubble and expansion crack origin of 'molar-tooth' calcite structures in the Middle Proterozoic Belt Supergroup, western Montana. J. Sed. Res., 68, 104-114.

Golubic, S. (1976) Organisms that build stromatolites. In: Stromatolites (Ed. M.R. Walter). Elsevier, Amsterdam, pp. 113-126.

Goodman, E.E. and Kah, L.C. (2004) Trace sulfate concentrations as an indicator of depositional environment: examination of some possible calcitized evaporates from the Proterozoic Atar Group, Mauritania. Geol. Soc. Am., Abstr. Prog., 36, 78.

Grey, K. and Thorne, A.M. (1985) Biostratigraphic significance of stromatolites in upward shallowing sequences of the early Proterozoic Duck Creek Dolomite, Western Australia. Precambrian Res., 29, 183-206.

Grotzinger, J.P. (1989) Facies and evolution of Precambrian depositional systems: emergence of the modern platform archetype. In: Controls on Carbonate Platform and Basin Development (Eds P.D. Crevello, J.J. Wilson, J.F. Sarg and J.F. Read). SEPM Spec. Pub., 44, 79-106.

Grotzinger, J.P. and Knoll, A.H. (1999) Stromatolites in Precambrian carbonates: evolutionary mileposts or environmental dipsticks? Ann. Rev. Earth Planet. Sci., 27, 313-358.

Grotzinger, J.P. and Rothman, D. (1996) An abiotic model for stromatolite morphogenesis. Nature, 383, 423-425.

Halverson, G.P., Hoffman, P.F., Schrag, D.P., Maloof, A.C. and Rice, A.H.N. (2005) Toward a Neoproterozoic composite carbon-isotope record. Geol. Soc. Am. Bull., 117, 1181-1207.

Hoffman, P.F. (1967) Algal stromatolites: use in stratigraphic correlation and paleocurrent determination. Science, 157, 1043-1045.

Hoffman, P.F. (1974) Shallow and deep-water stromatolites in lower Proterozoic platform-tobasin facies change, Great Slave Lake, Canada. AAPG Bull., 58, 856-867.

Hoffman, P.F. (1976) Environmental diversity of Middle Precambrian stromatolites. In: Stromatolites (Ed. M.R. Walter). Elsevier, Amsterdam, pp. 599-611.

Hofmann, H.J. (1969) Attributes of stromatolites. Geol. Surv. Can., Pap., 69-39, 80.

James, N.P., Narbonne, G.M. and Sherman, A.B. (1998) Molar-tooth carbonates: shallow subtidal facies of the Mid-to Late Proterozoic. J. Sed. Res., 68, 716-722.

Kah, L.C. and Knoll, A.H. (1996) Microbenthic distribution in Proterozoic tidal flats: environmental and taphonomic considerations. Geology, 24, 79-82. 
Kah, L.C., Sherman, A.B., Narbonne, G.M., Kaufman, A.J. and Knoll, A.H. (1999a) $\delta^{13} \mathrm{C}$ stratigraphy of the Proterozoic Bylot Supergroup, northern Baffin Island: Implications for regional lithostratigraphic correlations. Can. J. Earth. Sci., 36, 313-332.

Kah, L.C., Bartley, J.K., Frank, T.D. and Lyons, T.W. (1999b) Reef facies and possible chemosynthetic communities of the Sulky formation, 1.3 Ga Dismal Lakes Group, NWT, Canada. Geol. Assoc. Can./Mineral. Assoc. Can., Abstr., 24, 60.

Kah, L.C., Bartley, J.K., Frank, T.D. and Lyons, T.W. (2006) Reconstructing sea-level change from the internal architecture of stromatolite reefs: an example from the Mesoproterozoic Sulky Formation, Dismal Lakes Group, arctic Canada. Can. J. Earth Sci., 43, 653-669.

Kaufman, A.J. and Knoll, A.H. (1995) Neoproterozoic variations in the C-isotopic composition of seawater: stratigraphic and biogeochemical implications. Precambrian Res., 73, 27-49.

Knoll, A.H. and Semikhatov, M.A. (1998) The genesis and time distribution of two distinctive Proterozoic stromatolite microstructures. Palaios, 13, 408-422.

Knoll, A.H. and Sergeev, V.N. (1995) Taphonomic and evolutionary changes across the MesoproterozoicNeoproterozoic boundary. Neues Jb. Miner. Geol. Paläontol., 195, 289-302.

Knoll, A.H., Kaufman, A.J. and Semikhatov, M.A. (1995) The carbon isotopic composition of Proterozoic carbonates: Riphean successions from northwestern Siberia (Anabar Massif, Turukhansk Uplift). Am. J. Sci., 295, 823-850.

Lee, S.-J. and Golubic, S. (2000) Biological and mineral components of an ancient stromatolite: Gaoyuzhuang Formation, Mesoproterozoic of China. In: Carbonate Sedimentation and Diagenesis in the Evolving Precambrian World (Eds J.P. Grotzinger and N.P. James). SEPM Spec. Pub., 67, 91-102.

Lemon, N.M. (2000) A Neoproterozoic fringing stromatolite reef complex, Finders Ranges, South Australia. Precambrian Res., 100, 109-120.

Logan, B.W., Hoffman, P.F. and Gebelein, C.D. (1974) Algal mats, cryptalgal fabrics, and structures, Hamelin Pool, Western Australia. In: Evolution and Diagenesis of Quaternary Carbonate Sequences, Shark Bay, Western Australia (Eds B.W. Logan, J.F. Read and G.M. Hagan). AAPG Mem., 69, 140-194.

Pollock, M.D., Kah, L.C. and Bartley, J.K. (2006) Morphology of molar-tooth structures in Precambrian carbonates: influence of substrate rheology and implications for genesis. J. Sed. Res., 76, 310-323.

Miall, A.D. (1997) The Geology of Stratigraphic Sequences. Springer-Verlag, Berlin, Germany.

Moussine-Pouchkine, A. and Bertrand-Sarfati, J. (1997) Tectonosedimentary subdivisions in the Neoproterozoic to Early Cambrian cover of the Taoudenni Basin (AlgeriaMauritania-Mali). J. Af. Earth Sci., 24, 425-443.
Moussine-Pouchkine, A., Bertrand-Sarfati, J., Ball, E. and Caby, R. (1988) Les series sedimentaires et volcaniques anorogeniques proterozoiques impliquees dans la chaine pan africaine; la region de l'Adrar Ahnet (NW Hoggar, Algerie). J. Af. Earth Sci., 7, $57-75$.

Narbonne, G.M. and James, N.P. (1996) Mesoproterozoic deep-water reefs from Borden Peninsula, Arctic Canada. Sedimentology, 43, 827-848.

Reid, R.P., Visscher, P.T., Decho, A., Stolz, J.K., Bebout, B.M., Dupraz, C., MacIntyre, I.G., Paerl, H.W., Pinchney, J.L., Prufert-Bebout, L., Steppe, T.F. and DesMarais, D.J. (2000) The role of microbes in accretion, lamination and early lithification of modern marine stromatolites. Nature 406, 989-992.

Semikhatov, M.A. and Raaben, M.E. (1994) Dynamics of the global diversity of Proterozoic stromatolites. Article 1: Northern Eurasia, China, and India. Strat. Geol. Correl., 2, 492-513.

Semikhatov, M.A. and Raaben, M.E. (1996) Dynamics of the global diversity of Proterozoic stromatolites. Article II: Africa, Australia, North America, and general synthesis. Strat. Geol. Correl., 4, 24-50.

Semikhatov, M.A., Gebelein,C.D.,Cloud,P., Awramik, S.M. and Benmore, W.C. (1979) Stromatolite morphogenesis - progress and problems. Can. J. Earth Sci., 19, 992-1015.

Sumner, D.Y. and Grotzinger, J.P. (1996a) Herringbone calcite: petrography and environmental significance. J. Sed. Res., 66, 419-429.

Sumner, D.Y. and Grotzinger, J.P. (1996b) Were kinetics of Archean calcium carbonate precipitation related to oxygen concentration? Geology, 24, 119-122.

Teal, D.J. and Kah, L.C. (2005) Using C-isotopes to constrain interbasinal stratigraphic correlations, Mesoproterozoic Atar Group, Mauritania. Geol. Soc. Am., Abstr. Prog., 37, 45.

Tourre, S.A. and Sumner, D.Y. (2000) Geochemistry of herringbone calcite from an ancient Egyptian quarry. Geol. Soc. Am., Abstr. Prog., 32, 215.

Trompette, R. and Carozzi, A.V. (1994) Geology of Western Gondwana (2000-500 Ma). A.A. Balkema, Rotterdam, $340 \mathrm{pp}$.

Turner, E.C., James, N.P. and Narbonne, G.M. (1997) Growth dynamics of Neoproterozoic calcimicrobial reefs, Mackenzie Mountains, northwest Canada. J. Sed. Res., 67, 437-450.

Turner, E.C., Narbonne, G.M. and James, N.P. (1993) Neoproterozoic reef microstructures from the Little Dal Group, northwestern Canada. Geology, 21, 259-262.

Walter, M.R. (1992) Proterozoic Stromatolites. In: The Proterozoic Biosphere: A Multidisciplinary Study (Eds J.W. Schopf and C. Klein), Cambridge, New York, pp. 253-260. 
